\title{
HILGARDIA
}

A Journal of Agricultural Science Published by the California Agricultural Experiment Station

\section{MORPHOLOGICAL DEVELOPMENT OF THE} FRUIT OF JUGLANS REGIA

CHARLOTTE G. NAST 


\title{
$\begin{array}{lllllllll}H & \text { I } & \text { L } & G & A & R & D & \text { I } & \text { A }\end{array}$
}

A Journal of Agricultural Science Published by

the California Agricultural Experiment Station

Vor. 9

MAY, 1935

No. 7

\section{MORPHOLOGICAL DEVELOPMENT OF THE FRUIT OF JUGLANS REGIA ${ }^{1}$}

\author{
CHARLOTTE G. NAST ${ }^{2}$
}

\section{INTRODUCTION}

A MAJOR PORTION of the literature concerning the floral morphology of Juglans regia L. was published in the latter part of the Nineteenth Century and early Twentieth by French and German workers. Hicoria pecan, on the other hand, has been investigated within the last five to eight years by English and American workers. Van Tieghem, ${ }^{(15)}$ the first to publish on the morphology of Juglans species, was interested in proving, to uphold his theory of parietal placentation, that the orthotropous ovule of the walnut is really an anatropous ovule, inserted on a single edge of one of the two sporophylls of the pistil. He used the vascular anatomy in this work and thus reported the number of bundles arising from the floral pedicel and the branches resulting from them. Errors have been found, especially in his interpretation of the ventral carpellary system. He also studied abnormal fruits to show that at one time in the phylogeny of the fruit there were four anatropous ovules, three of which have since aborted, leaving only the ovule traces to indicate their previous existence. He reported, therefore, that four ovule branches arise from each of the four marginals, but only one terminates in the ovule. The other three are the traces to his so-called "aborted ovules." No other workers have reported this condition except Benson and Welsford, ${ }^{(2)}$ who agree with him in all respects. They consider the placental bundles as built up of leaf traces diverging at the base of the flower and depict fruits with the two placental bundles of unequal size. They have, however, no illustrations of the three nonfunctional traces, but merely agree with Van Tieghem's explanation of such a situation.

1 Received for publication December 8, 1934.

2 Associate in Pomology. 
According to Van Tieghem ${ }^{(15)}$ six bracts constitute the perianth. De Candolle, ${ }^{(5)}$ on the other hand, compared the pistillate flower with the staminate flower, which has all the flower parts distinct. He believed that the pistillate flower was formerly like the staminate, that the bract united with the two "prophylles" to form a "perigone exterieur," and that the four perianth lobes united to form a "perigone interieur." These two regions fused with each other and then united with the pistil. All the others workers-Nicoloff, ${ }^{(11)}$ Braun, ${ }^{(4)} \mathrm{Holm},{ }^{(6)}$ Lubbock, ${ }^{(9)} \mathrm{Kar}-$ sten, ${ }^{(7)}$ and Benson and Welsford ${ }^{(2)}$-agreed as to the number of parts given by De Candolle but used Nicoloff's terms of "involucre" for the outermost region and "perianth" for the inner region. These workers also described the anatomy of the flower, and Nicoloff and Karsten worked upon the macrogametophyte development. Woodworth ${ }^{(19)}$ reported 16 pairs of chromosomes in Juglans.

The development of the pistillate flower, from the time of the appearance of the first floral parts until the development of the embryo, has been studied and is herewith reported. The vascular anatomy has been traced to help interpret the floral parts, to correct errors in the work of earlier authors, and to compare it with the unusual vascular system of Hicoria pecan as given by Schuhart. ${ }^{(13)}$

The material on which these studies were made was collected at Davis, California. Formalin-alcohol and formalin-acetic-alcohol fixatives were used and the paraffin method of embedding was followed. Material was cut 7-20 microns and stained with safranin-Delafield's haematoxylin for general morphological study, and with Flemming's triple stain or Haidenhain's haematoxylin with or without light-green counter-stain for cytological details.

\section{FLORAL DESCRIPTION}

The outermost portion of the pistillate flower of Juglans regia is made up of a hairy involucre (plate 1 , fig. $1 D$ ) which represents morphologically the union of one bract with two bracteoles or "prefuilles." $(2,4,6,7,8,10)$ The two bracteoles are united the full length so that there is no indication of the union except at the apex, where they separate from the perianth in a fringe of tissue, slightly undulated at its edge (fig. $1 B$ ). The bract (fig. $1 A$ ) is present as a small toothlike projection that may separate from the perianth slightly lower than the bracteoles. It is opposite that suture of the shell of the nut which is located abaxially in the two-flowered inflorescence. In cross sections of young flowers the side of the involucre, made up of the bract, usually protrudes, forming a bump or bulge. In the basal part there is one large distinct bundle (plate 18, 
fig. $67 \mathrm{~K}$ ), which later breaks up into smaller branches and enters the toothlike appendage of the bract. Nicoloff ${ }^{(11)}$ also pictured this prominence but did not notice the vascular bundle. He believed the structure further substantiated De Candolle's theory ${ }^{(5)}$ that this portion of the involucre or "perigone exterior" actually has been formed from a bract. The bundle, which branches from the pedicel vascular ring slightly before the other involucre bundles, seems to indicate also that the abaxial side of the involucre is composed of a structure borne lower down on the pedicel and that this structure may be considered bract-like in nature.

The perianth, or "perigone interior" of De Candolle, ${ }^{(5)}$ contained within and united to the involucre, is terminated by four parts which are from three to five times longer than the bract (fig. $1 C$ ). The places of union of the four parts to one another, and the union of the perianth itself to the involucre, are not marked by any structural difference of the tissue. In the lower half of some flowers the vascular bundles tend to be grouped into four regions. This may indicate the four parts of the perianth. Two of these leaflets are borne slightly lower than the others.

The pistil consists of a large, spreading, bifurcated stigma (fig. $1 E$ ) whose surface is very irregular, and an ovary composed of two carpels that become hard or stony at maturity (plate 7 , figs. 43,44 ). Two septa are present in this ovary. One, the major septum (plate 7, figs. 41A, 44A, and marked off by ink in plate 15, fig. 61 and plate 16 , fig. 63 , at $P$ ), is considered the composite of the ventral edges of the sporophylls and divides the ovary into two parts except in the region of the ovule (plate 7 , fig. $41 G, 43 G$ ). Thus there is really only one cell or ovarian cavity where two would normally be formed. The second septum bisects each carpel at the apex and base, forming four regions at the bottom and top of the ovarian cavity. This septum (fig. $38 B$ ) is in the same plane as the shell sutures (fig. 40M), which are the dorsal sutures of the two earpels. The one in the upper portion of the fruit, however, is split by the dorsal sutures so that it is in two parts (plate 6, fig. $34 H$ ). The hypo$\operatorname{cotyl}^{3}$ end ( $H$ in plate 7 , figs. 39,42 ) of the seed lies in this split. The four points of the cotyledons ( $I$ in figs. 39,42 ) at each end of the seed lie in the four cavities formed by the two septa in the upper and lower part of the locule. The seed shown in figure 39 is placed as it would lie in the shell in figure 37 , and the seed in figure 42 as it would lie in the shell in figure 40.

\footnotetext{
3 The term hypocotyl is interpreted literally and is, therefore, used here for all parts of the embryo in the seed below the attachment of the cotyledons.
} 


\section{FLORAL DEVELOPMENT}

The first indication of floral development of Juglans regia L. (Concord variety) in 1930, occurred in material collected on February 25 at Davis. Earlier, on February 11, only a rounded meristematic floral axis was present. The axis first becomes flattened (plate 2, fig. 3) and then gives rise to the involucre (fig. $4 A$ ). In a few instances the bract seems to appear first, but in most of the material the involucre appears as a ring of tissue. The perianth (fig. $5 B$ ) arises as a second ring of tissue, but soon becomes divided into the four perianth leaves. Growth slows up for about ten days, during which time the axis enlarges as a whole. On March 15, 1930-17 days after the appearance of the involucre-the carpels (fig. $6 C$ ) arose as a ring of tissue. A depressed region (6D) is thus left at the apex of the stem. Whether or not the carpel edges remain unfused for a short time, as depicted by Schuhart ${ }^{(13)}$ in Hicoria pecan, was not determined. The rate of growth is then accelerated. Material collected one week later contained all stages from the beginning of the central placenta (fig. $7 E$ ) to the appearance of the ovule with the macrospore mother cell already divided (fig. $11 F$ ). The placenta arises as a central column free from the carpel wall ( $E$ in plate 2, figs. 7,8 , and in plate 6 , fig. 31 ). The ovule (plate 2, fig. 9I) is borne at the apex of this central columnar placenta within a day or two after the formation of the latter. The style at this time is more pronounced, and the involucre and perianth are carried upward by intercalary growth in the region marked $A$. The result of this intercalary growth can be readily seen in figures 7,8 , and 9 as the parts are carried still higher, leaving the central placenta with the ovule located in the middle of the longitudinal plane of the flower. The perianth in particular seems to be carried very high, so that in a mature flower its parts appear to arise from the style (fig. 11, and plate 5, fig. 28A). Provascular strands (fig. 9H) in this material indicate that the involucre and perianth-carpel bundles branch and separate directly from the pedicel at the base of the flower and that no central strands continue up to the ovule or central column.

In the development of the major septum, according to Nicoloff,, ${ }^{(11)}$ the bottom of the ovarian cavity is at first concave but later begins to arise in a region perpendicular to the plane of stigmas, accompanied by a cessation of growth in the remaining portion. This development occurs before the differentiation of the stigmas and the formation of the ovule. In sections of very young flowers of the Concord variety studied here, there is no concave bottom, but the central placenta fills the entire base of the ovarian cavity (fig. $7 G$ ). The first indication of the septum 
is a separation of cells in two lines on each side of the placenta (plate 6, fig. $35 \mathrm{~A}$ ). The walls of the cells in these two regions do not adhere, but, with further growth of the flower, gradually separate, forming two "cracks" in the lower part of the ovary (plate 6, fig. 31A). The intercalary growth that pushes the perianth higher also aids in forming the cavities and septa. Growth in the region $A$ (plate 2, figs. 7, 8, 9, 10) not only elongates the "walls" of the flower but increases the diameter of the flower by increasing the circumference of the involucre, perianth, and carpels. The elongation of the "walls"-that is, involucre, perianth, and carpel-together with the elongation of the septum, growth of which keeps pace with the "walls," deepens the cavity on each side of the major septum (plate 6, figs. $31 A, 32 A$ ). Because the circumference increases, the "walls" bulge outward, thus increasing the width of the cavity (fig. 32 ) and also eventually producing a concave bottom. At the same time that the "walls" (involucre, perianth, and carpel) are enlarging, the septum grows in the radial plane of the flower (arrows at $B$ in fig. 33) so as to keep pace with the increase in the diameter of the flower. If this did not occur, the position of the major septum would be marked in the fruit by two indentations similar to sutures. Thus this septum does not grow towards and attach itself to the ovarian wall, ${ }^{(11)}$ but is from the very beginning joined to it.

The second septum, perpendicular to the plane of the first or major septum, arises similarly. First, the cells separate (fig. 36A) in four places at the base and apex of the ovary; then, by cessation of growth at these places and an increase in growth rate of the tissues of the "walls" and of the arising septum, this partition becomes prominent. The second septum in the basal region of the ovary is never so high as the major septum, since it starts growth later (fig. $33 \mathrm{C}$ ). The dorsal sutures in a mature fruit extend through this basal septum which usually splits, if the sutures are weak, into two parts when the "nut" is cracked open. The second septum at the apex (fig. $34 H$ ), however, is actually separated by the sutures (plate 15, fig. $60 \mathrm{~N}$ ) into two parts (fig. 600 ) early in its development, because the dorsal sutures are more weakly formed at that end. It is in this separation or split that the hypocotyl end (plate 7, fig. $42 H$ ) of the seed lies. If, therefore, the fruit is cut through the dorsal sutures, as in figure 38 , the second septum will be seen at the base $(B)$ but not at the apex, since the cut is through this split. The apical septum is located as far down as $K$ in figure 38, and the basal septum extends as far as $L$, thus leaving the region of the carpels between $K$ and $L$ unbisected. Examining the seed in figure 42, we find grooves left in the cotyledons at $C$ by the two halves of the apical septum and at $D$ by the basal septum, while region $E$ is the place where the car- 
pels were unbisected by the septum. The contour of the inside of the ovarian cavity is therefore changed at both extremities to four depressions by the formation of this second septum.

Workers seem to disagree on the nature and function of the two winged evaginations that arise about the time of macrospore tetrad formation. These structures arise slightly before the second septum appears. They are outgrowths (plate 5 , fig. $28 B$; plate 16 , fig. $63 Q$; plate 17 , fig. $64 Q$ ) from the major septum at the center of the flower. Since that region is really the composite of the ventral carpel edges, it can be considered as placenta, and the winged evaginations would therefore be placental outgrowths. The evaginations grow toward the periphery of the flower, but there is always a distinct line of separation between them and the carpel wall (plate 5, fig. $29 C$; plate 17, fig. $64 R$ ). The cavities produced by the major septum and later those formed by the second septum are filled with these structures, the growth of which keeps pace with the enlargement of the cavities. The winged evaginations when mature are made up of large, thin-walled cells that radiate from (plate 5, fig. 29D) the central placenta. After fertilization and during the rapid development of the endosperm, the evaginations disintegrate (plate 19, fig. 69Q).

\section{MACROGAMETOPHYTE AND SEED DEVELOPMENT}

The complete development from the macrospore mother cell to the onecelled embryo occurs within seven to twelve days in Juglans regia. The length of time and the dates for this development vary in different seasons for the same tree. Material collected in 1930 had finished this development on April 5, fertilization occurring, therefore, during the first of April; whereas material collected in 1932 showed an earlier development, one-celled embryos being found on March 28. Material collected on March 26, 1932, was in the four-nucleated stage; thus only two days were necessary in 1932 for forming the eight-nucleated gametophyte and for completing fertilization.

A distinct macrospore mother cell is located approximately in the center, two to five cells within the nucellus (plate 3 , fig. 12). This cell is many times the size of the adjacent nucellar cells, and the nucleus is correspondingly large. The integument primordium, $A$, is first noted at this stage; but no winged evaginations are discernible. The cytoplasm of the macrospore mother cell is very dense and has small vacuoles (fig. 13). Although no meiotic figures were observed, reduction division presumably occurs, since two spores and then four spores, or the usual linear tetrad, are found (figs. 14, 15). With increase in size of the cells, 
the cytoplasm becomes less dense and more vacuolated. The spore at the chalazal end of the tetrad (fig. 15A) develops into the gametophyte. The other three normally degenerate. The two center cells of the tetrad are usually smaller and soon disintegrate; the cell at the micropylar end in most cases is larger and possibly develops into a second embryo sac, which, in numerous cases, has been found lying directly above the normal sac. This second embryo sac is smaller and possibly functions only if the normal one is destroyed. According to Karsten, ${ }^{(7)}$ some of the accessory embryo saes lie at the side of the normal sac with from none to several cells intervening. These, he believes, arise from separate macrospores. The others-those lying end to end or directly above one another-he believes arise from the third cell of the tetrad. This cell, which is very small, is one of the first to disintegrate in the variety of Juglans regia studied here. Of the three, only the cell nearest the micropyle looks as though it could continue development.

The characteristic shape of the macrogametophyte is determined in the tetrad stage. At this time it is small, usually pointed at the chalazal end, and generally enlarged and rounded at the micropylar end, where a large vacuole is located (fig. 16, 17). The cell and its nucleus increase in size before nuclear division occurs. After the first division the two resulting nuclei lie in opposite ends of the cell in extremely dense cytoplasm. The vacuole enlarges and moves to a central position (fig. 18).

The cells of the nucellus around the embryo sac begin at this time to elongate longitudinally with the axis of the flower, and they continue to do so in all subsequent stages. The cells at the periphery of the nucellus remain fairly isodiametric. The embryo sac lies eight to ten cells in from the periphery and seldom becomes embedded more than twelve cells at the time of fertilization.

The integument ensheaths the nucellus about two-thirds its length at the two-nucleated stage of the macrogametophyte. In the four-nucleated stage it practically encloses the end of the nucellar tissue, which it completely envelops when eight nuclei are present. The integument becomes elongated and extended; after fertilization it fills the upper ovarian cavity (plate 5, figs. 29,30 ).

The winged evaginations grow as far as the base of the integuments in the two-nucleated stage ( $B$ in fig. 28). Their greatest development is reached shortly after fertilization, when they have grown as high as the apex of the conical nucellus ( $E$ in fig. 29). Nicoloff ${ }^{(11)}$ has reported them as developing beyond the tips of the integuments at the time of fecundation.

The two spindles of the second division of the macrospore lie in opposite ends of the sac and in opposite planes (plate 3, fig. 19). The 
spindle of the chalazal end lies parallel to the long axis of the sac; the other spindle, in a transverse plane. The resulting nuclei usually arrange themselves as shown in figure 21, although in a few instances they were all found in the micropylar end of the sac (fig. 20). The chalazal end is always filled with dense cytoplasm, so much so at times that the nuclear membrane of the nucleus is poorly defined (fig. 21). The remaining cytoplasm in most cases is stringy and highly vacuolated.

The random placement of the spindles of the third division in plate 4, figure 22, may not be typical, since, as has been stated previously, in the four-nucleated stage one of the nuclei is usually found in the chalazal point of the sac. This displacement in figure. 22 may have resulted from plasmolysis.

The completely formed embryo sac (fig. 23) has dense cytoplasm at both ends. The three antipodal cells are small and are packed into the pointed, denser end of the gametophyte. The egg apparatus consists of two synergid cells which are at first short but which may later elongate (fig. 24), and an egg cell which is in all appearances like the synergids except that it is located slightly toward the center of the macrogametophyte (fig. 25). There is usually no indication of size difference between the egg and synergids in the material examined, as has been reported by Karsten $^{(7)}$ and Nicoloff. ${ }^{(11)}$ The polar nuclei are slightly larger than the others and have decidedly larger nucleoli (fig. 23). Endosperm nuclei are like the polar nuclei in this respect (fig. $26 \mathrm{~A}$ ).

Chalazogamy, as reported by Nawaschin, ${ }^{(10)}$ usually occurs (plate 5 , fig. $29 B$ ), although a few pollen tubes were seen to enter the micropyle. This seems to happen, however, only when the integuments are touching the ovarian wall. The pollen tubes may travel through the winged evaginations to the chalazal end, but they were found almost as often to grow on the upper edge of the winged formation and to enter the chalaza without penetrating the evaginations.

Immediately after fertilization the antipodal cells disintegrate, and the characteristic pointed end of the macrogametophyte disappears. The synergid cells also disintegrate, but more slowly. Their cytoplasm first becomes very dense, and the cells lie close to the zygote (plate 4, fig. $26 B$ ). Later they collapse. The fertilized egg (fig. 26C) attaches itself firmly to the micropylar end of the sac, remaining as a single cell structure until the endosperm is composed of as many as a thousand nuclei. This one-celled embryo contains fairly dense cytoplasm and a nucleus about the same size as that of the egg. Several embryo sacs were found with all of the endosperm nuclei in the same stage of division (fig. 27), a fact which is contradictory to Miss Langdon' ${ }^{(8)}$ belief that amitotic division occurs in the endosperm of $J$. mandshurica. This simultaneous division 
multiplies the number of nuclei rapidly. Along with nuclear multiplication goes a tremendous increase in the size of the cell, caused primarily, since there is only a thin layer of cytoplasm ( $A$ in plate 8 , fig. 46 and in plate 9 , fig. 47 ), by an enormous central vacuole (fig. $47 E$ ). The integument ( $C$ in figs. 46,47 ) and the nucellus ( $B$ in figs. 46,47 ) also develop rapidly, although not necessarily in thickness. They fill the space (plate 8 , fig. $45 \mathrm{~A}$ ) left by the evaginations, which disintegrate after fertilization. Thus the shape of the ovule is changed into the characteristic, irregular shape of the seed. The beginning of this development is shown in the fruit in figure 45 , which is cut through the second septum. The basal part of the ovule grows down into the four cavities formed by the septa, and the upper part of the ovule grows into the four upper cavities. The shape of the seed is formed by the growth of the integument, nucellus, and endosperm, which nearly gain their complete development before the embryo is of any appreciable size.

The embryo is the "meat" of the walnut. Its growth is at first slow. In plate 8 , figure 45 and plate 9 , figure 47 the embryo at $D$ is composed of 8 cells and occupies only a small space in the developing seed. When the embryo is $32-64$ cells, or approximately six weeks after fertilization, cell walls begin to form in the endosperm. The embryo in its growth gradually pushes the endosperm at the apex down into the vacuole and towards the chalaza. The endosperm tissue in an ovule $3 \mathrm{~cm}$ long is about as thick as the nucellus-that is, $1 / 4 \mathrm{~mm}$. The vacuole, though still present, is smaller because of the encroachment of the elongating embryo, which, in this size ovule, grows to approximately $13 \mathrm{~mm}$ (fig. 48) and is located in the central cone at $H$, plate 7 , figure 42 . The cotyledons lie in the fruit so that the second septum separates the two, while the major septum almost bisects each cotyledon. In figure 42 one cotyledon would lie to the left of a line drawn from $C$ to $D$. In figure 39 one cotyledon is in the foreground and shows the groove left by the major septum which practically dissects it.

Although the cotyledons of this half-inch embryo (plate 9, fig. 48B) are not long enough to be affected by the contour of the rest of the ovule, they are beginning to assume an irregular shape. Each cotyledon is bilobed, and each lobe (fig. 48A) is folded upon itself. Thus in a mature embryo each half of a cotyledon or a quarter of the "meat" can be easily separated in the center (plate 7 , figs. 43,44 , at $J$ ) because of the folding of the cotyledonary lobe. The papery tissue found in this fold of a mature seed is the remains of the endosperm, which, being pushed down by the growing cotyledons, is forced within the folds. 


\section{VASCULAR ANATOMY}

Schuhart ${ }^{(13)}$ describes a peculiar situation in Hicoria pecan where the outer cycle of bundles turns at the apex of the fruit, after traces have branched to the perianth, and then descends the length of the fruit with the xylem reversed or facing the periphery. These bundles again turn at the base of the fruit, entering the septa normally oriented. The ovule bundles also are reversed but turn at the bottom of the ovule, thus producing bundles in the integument with xylem again in a normal position. He finds no bundles from the floral pedicel entering the second or reversed cycle. He also mentions the vascular system of Juglans regia. In it he finds the bundles dispersed as a meristem at the base of the cupule, the inner bundles in the ovarian region with reversed orientation or of bicollateral nature, the septal bundles arising as in Hicoria pecan, and the dorsals diverging from stelar bundles of normal orientation. As the pistillate flower of Juglans regia is not identical with that of Hicoria pecan, the vascular systems would not be expected to be the same. The involucre, not present in the pecan, produces a more complicated vascular system in the walnut.

Both mature fruits and flowers were used to study the vascular system. Mature fruits, similar to the one shown in plate 1, figure 2, were placed in an eosin solution. The involucres of some of these fruits were then peeled off down to the bundles (plate 10, figs. 49, 50). Other fruits were cut in various ways - at the shell sutures (fig. 52) and at right angles to the shell sutures (fig. 51). Cross sections of a flower (figs. 5568 in plates 13-19) cut at the levels shown in the diagram, plate 11, figure 53 , show the number of bundles and their position in the floral parts. In plate 16, figure 62, these floral parts are as follows: the husk or involucre at $A$, the perianth and a small outer portion of the carpel in the region at $B$, the shell or the greater part of the carpel wall at $C$, the dorsal suture which is the nut suture at $N$, and the major septum at $P$.

The pedicel contains a ring of vascular tissue that breaks up into ten to twelve bundles at the base of the flower (plate 19, fig. 68). Ten to twelve main bundles branch from this ring (plate 18, fig. 67L) and then ascend into the involucre. One of these main bundles leaves the vascular ring slightly lower down than the other ten or twelve (at $K$ in plate 17, fig. 65 ; in plate 18 , figs. 66,67 ; and in plate 19 , fig. 68 ). It is on the side of the bract, and its branches eventually enter that structure.

In plate 10 , figure 49 , which shows the basal end of the fruit with the outer part of the involucre removed, eleven of these main bundles arise from the pedicel at $A$ and then branch in two planes-that is, tangential 
(fig. $49 B$ ) and radial (at $C$, plate 10 , figs. 51, 52). The resulting bundles continue to break up into smaller ones so that the upper half of the fruit (fig. $50 \mathrm{~B}$ ) contains a mass of bundles. The tangential branches form an outer ring of vascular bundles located in the outer part of the involucre tissue. These bundles are the main involucre bundles and are of normal orientation - that is, the xylem is located on the side towards the center of the fruit. The radial branches at the base of the fruit (plate 10, figs. 51,52 , at $C$ ), which are also of normal orientation, join a second ring of vascular tissue, which is here called the perianth-carpel cycle (at $S$, plate 14, fig. 58 and plate 16, fig. 63) because these bundles are more or less fused and lie in the perianth-carpel tissue (fig. 62B), the parts of which are inseparable. The radial branches in the upper part of the fruit are not all of normal orientation, but turn and twist in their course to the perianth-carpel cycle (at $B$ in plate 11, fig. 53 ; and in plate 12 , fig. 54), joining it as normal, reversed, or partly reversed bundles. The involucre region between the main outer involucre cycle and the perianth-carpel cycle has therefore many small bundles, variously oriented because they are the radial branches $A$ and $B$ shown in figures 53 and 54 . The lower ones at $A$ are of normal orientation; the upper ones at $B$ are twisted and consequently variously oriented.

Besides the branches that come from the involucre, the perianth-carpel cycle is also composed of the bundles that continue directly up into the fruit (plate 10 , fig. $51 D$, plate 18 , fig. $67 S$, plate 11 , fig. $53 D$ and plate 12 , fig. $54 D$ ). These bundles are normally oriented. The perianth and carpel bundles do not separate until they reach the level 2 (fig. 53) or a point slightly below that. The perianth bundles (fig. $53 E$ ) then turn off and enter the perianth lobes ( $E$ in plate 13 , figs. $55,56,57$ ). Each perianth lobe receives three to five bundles. The carpel bundles, including the large dorsal bundles (fig. 57G), continue into the style, where they gradually become smaller and disappear. No turning of bundles comparable to that found in Hicoria pecan is present at the apex of the flower.

The ventral and dorsal bundles are first united with one another and arise near the dorsal sutures from the perianth-carpel ring of bundles. There are four of these bundles of the perianth-carpel cycle that ascend from the pedicel and come together two by two at each suture of the shell. These mingle but do not unite. Each of the four bundles which have here been called the dorsal-ventrals is composed of one ventral and a half a dorsal. The dorsal-ventral bundles ascend to level 11, plate 11, figure 53 , where the ventrals (plate 17, fig. $65 H$ ) separate from the dorsals (fig. $65 G$ ), making four bundles at each suture at this level instead of two. The xylem elements of the two ventral bundles turn toward each 
other (fig. 65 and plate 18, fig. $66 \mathrm{H}$ ) as they descend and make a complete twist (plate 12, fig. 54) as they take a horizontal course towards the center of the flower. The xylem in region 12 (shown also in plate 18, fig. 66 ) faces the pedicel, and the phloem the floral apex. The ventral bundles upon ascending toward the septa are thus, because of this twisting, readjusted for normal orientation.

Accessory bundles, added to the ventral bundles from the perianthcarpel cycle, are indicated at $I$ in the diagram in plate 11, figure 53, which depicts the bundles in a plane at right angles to the plane shown in plate 12 , figure 54 - that is, at right angles to the dorsal sutures. Two or three of these accessory bundles arise on each side of the flower (plate 18, fig. 66I). Together with the ventrals, they form at the base of the flower the two convex ares (plate 17, fig. $65 H$ ) described by Van Tieghem. ${ }^{(15)}$ In a region about half the distance to the ovule these ares break up into a number of bundles, through which the winged evaginations (plate 5, fig. $30 \mathrm{~A}$; plate 11 , fig. $53 \mathrm{H}$ ) are apparently nourished. Above this region are found four distinct bundles, the ventral or marginal bundles of the carpel ( $H$ in plate 16, fig. 63 and in plate 17, fig. 64). These continue vertically ( $H$ in plate 15 , fig. 61 and in plate 16 , fig. 62 ), two in each septum, to about the height of the apex of the nucellus (plate 11, fig. 53, level 6), where they unite and form two cylindrical masses of vascular tissue (plate 15, fig. 60H). Thence two bundles or ovule traces, onè on each side of the ovule, descend and at the same time move towards the ovule ( $T$ in plate 15 , fig. 61 , and in plate 16 , fig. 62 ), uniting into a ring of vascular tissue (fig. $62 U$ ) from which approximately twelve bundles (fig. $61 U$ ) branch to the integument. The twelve redivide, producing approximately twenty-four or thirty bundles in the upper portion of the ovule (fig. $60 \mathrm{U}$ ). The xylem of these two ovule bundles is reversed in their descending course; but, as the bundles turn to enter the funiculus, the xylem again is normally oriented for the integuments.

The two halves of each dorsal bundle (plate 17, fig. 65G) continue to ascend to the style after the ventral bundles $(H)$ have separated. These halves come to lie close together (figs. $64 G, 62 G$ ) in their upward course and unite at the apex of the flower (plate 13, fig. 57G; plate 14, fig. 58G). Branches from the perianth-carpel system may be added to the dorsal bundles throughout their length. Each dorsal bundle is accompanied on its outer side by a perianth bundle, which later breaks up into three or more branches that enter the lowermost set of perianth leaves. In the basal part of the style the dorsal bundles ( $G$ in plate 13 , figs. 55, 57) are very distinct, and two branches may diverge from each. The dorsal bundres gradually become smaller in the upper part of the style, where they eventually terminate. 


\section{DISCUSSION}

Van Tieghem ${ }^{(15)}$ reported the exact number of bundles arising from the floral pedicel and the branches resulting from them. In the material reported here, however, the number of bundles varied greatly in both the involucre and perianth-carpel systems. Nicoloff, ${ }^{(11)}$ who did not venture to give exact counts of bundles, reported that the two anterior and two posterior bundles of the inner ring (my perianth-carpel cycle) produce four bundles that run vertically, unite two by two, and end in the stigmas. Both he and Van Tieghem considered these to be dorsals. The ventrals, according to Van Tieghem, arise from four bundles that remain in the center of the pedicel after the perianth and dorsal bundles have been formed. These, he said, continue upward into the style. The ventrals arise most decidedly from the dorsal-ventral bundles and not directly from the pedicel. Which bundles he considered ventrals in the style is a question unless he misinterpreted as ventrals the bundles branching from the dorsals $(J$ in figs. 55,56$)$ in the style.

The ventrals do not arise from the base of the four "dorsal" bundles (Nicoloff) and then move inward, but branch off higher up and swing down again before turning toward the center. The turning and twisting of the bundle to readjust the orientation of the xylem resembles that found in transition regions of stems. The ventrals show their double nature below and above the region of accessory bundles; and the double nature of the dorsal bundles probably results from the occurrence of the shell suture in that region. The dorsal bundle is double in other plants where the fruit dehisces on the dorsal side of the carpel. Such is the case in Pisum. The walnut, therefore, may still be considered as having the usual three main bundles per carpel, but with modifications to take care of the orthotropous ovule.

Whether the ovule is borne on the continuation of the floral axis or on the united carpel edges is a debatable question. If the ovule is purely axial in nature, it would seem that the central system of bundles should arise not from the dorsal-ventrals, but directly from the vascular cylinder of the pedicel. One point favoring the axial theory is that a central column, which I consider a central-columnar placenta, arises slightly before the septum appears. This column might also be considered the elongation or continuation of the floral axis. If, however, longitudinal sections of older flowers cut through the septum are examined (fig. 30), there is no central column, but the ovule is borne directly upon the united carpel edges. These edges, which form the septum, are united two-thirds the length of the carpels. They then diverge to make room for the ovule 
and at the same time produce a single locule in the upper ovarian region. The ventral bundles can be considered as always located on the carpel edges, first at the center of the flower and later in the diverging septum or carpel edges. The ovule traces swing down and away from the ventrals as in other plants. The carpel vascular system is, however, peculiar in that there is a union of these two traces at the chalaza. The only explanation of such a phenomenon would be that Juglans regia at one time in its phylogeny possessed two ovules, one of which aborted, leaving its trace to unite with the trace of the normal ovule. Some workers ${ }^{(2)}$ have reported one of the traces smaller than the other. May this not be $\dot{a}$ degeneration of the trace to the once-present ovule?

Let us turn now to Van Tieghem's theory that Juglans formerly had four ovules. It is difficult to interpret just which vascular strands he refers to as the four ovule traces that branch from the four ventral bundles, three of which he believes are the traces to the aborted ovules. If he means the four central bundles that have been considered ventrals here, then my dorsal bundles would have to be his four ventral bundles, and there would be no bundles left for his dorsals. If, however, he did consider as ventrals the bundles which I have called dorsals, then his report of the presence of ventral bundles in the style is easily understood. No termination of these so-called four "ovule traces" occurs, however, to indicate that three of them formerly fed ovules which have since aborted. To be sure, the normal number of ovules in two carpels is four, and only one ovule is present in Juglans' two-carpelled flower; but to interpret the position or even the occurrence of the three aborted ovules does not seem consistent with the vascular construction of the present species. One can only find indications of one of those three aborted structures in the two traces that unite at the chalaza.

If the axial theory is discarded for the foliar theory, the so-called "central column" that arises almost simultaneously with the septum would have to be considered either as an advance nucellar growth or as a columnar placenta.

The winged evaginations have been interpreted in various ways. Nicoloff ${ }^{(11)}$ considered them as arising at the expense of the septa. Benson and Welsford ${ }^{(2)}$ compared them morphologically with the hairs borne on the placentae and funiculus of the ovules of Populus and Salix, though the functions are different. In the walnut, they considered them "packing tissue." Billings ${ }^{(3)}$ called the wings placentae; Karsten, ${ }^{(7)}$ the second integument. Nawaschin ${ }^{(10)}$ suggested, and Karsten and Billings agreed, that the special function of these winged structures is to produce an easy path to the chalaza for the pollen tube. I consider the evaginations as placental outgrowths that do not become attached to the ovarian 
wall, since a definite line of separation seems to be present at all times. These outgrowths are composed of thin-walled parenchyma cells, comparatively large, which start disintegration (plate 19, fig. 69) soon after fertilization when the endosperm rapidly develops. Thus the evaginations may be considered as temporary storage structures, comparable to the placental "outgrowths" of Lycopersicum esculentum. The fact that the pollen tubes do reach the embryo sac without entering the wings, a condition also reported by Nicoloff, would lead one to consider them unnecessary for fertilization.

Karsten $^{(7)}$ believed there is unlimited sporogenous tissue in the center of the nucellus, basing his statement upon the fact that more than one embryo sac may be formed. These saes, according to him, may arise from one macrospore mother cell, or from two macrospore mother cells that may divide into daughter cells or complete their development without division. Unfortunately, he neglected to depict this latter type having several rows of intervening cells, though illustrations of them might help in interpreting how they arise. Nicoloff ${ }^{(11)}$ also reported the presence of a sporogenous region. In Juglans regia, variety Concord, there is a definite macrospore mother cell, and only one was found in all the ovules sectioned. Since several ovules contained two embryo sacs, these second sacs must have arisen from the macrospore nearest the micropyle -the only one that shows possibilities of further development. If there is unlimited sporogenous tissue in the center of the nucellus, one would expect to find two or more macrospore mother cells developing in one ovule. This seems not to be the case.

The macrogametophyte is an eight-nucleated, seven-celled structure similar to that of Hicoria pecan, ${ }^{(18)}$ but unlike the pecan in that the development is more rapid. Pollination occurs not at the four-megaspore stage as in pecan ${ }^{(16)}$ but at the four or eight-nucleated embryo sac stage. Fertilization takes place within two to five days in Juglans regia-a much shorter time than the four to nine weeks ${ }^{(1,17)}$ in Hicoria pecan.

\section{SUMMARY}

The pistillate flower of Juglans regia consists of an involucre composed of a bract and two bracteoles, a four-lobed perianth, and a one-celled, two-carpelled ovary terminated by a bifurcated stigma. The main septum forms the ventral edges of the carpels. The two dorsal regions are located at the shell sutures. The ovule is orthotropous, with one integument.

Floral development is acropetal. The parts arise in the following sequence : involucre, perianth, ovary, central placenta, septa, ovule, in- 
tegument, and winged evaginations. Development up to the tetrad stage is completed in about one month.

The winged evaginations are interpreted as placental outgrowths, which function as storage organs.

There is a distinct macrospore mother cell, which undergoes reduction division and produces a linear tetrad of macrospores.

The typical angiosperm eight-nucleated, seven-celled macrogametophyte is formed from the macrospore at the chalazal end of the tetrad. The antipodal cells are small and are located in the pointed end of the sac. There is no difference in the size of the synergid and egg nuclei, nor in the cells. The polar nuclei are the largest and contain large nucleoli. The development from macrospore mother cell to macrogametophyte is completed in a week to twelve days.

The integument is formed before the winged evaginations and completely encloses the nucellus at the eight-nucleated stage of the macrogametophyte.

Fertilization takes place two to five days after pollination. Chalazogamy usually occurs, although the pollen tube does not necessarily enter the chalaza through the winged evaginations.

The endosperm nuclei divide simultaneously. There are approximately a thousand nuclei in the endosperm before the embryo starts division. A large central vacuole is present in the endosperm.

The integument, nucellus, and endosperm assume the characteristic shape and practically the full size of the mature seed before the embryo is $13 \mathrm{~mm}$ long. In the mature seed the endosperm is present as a thin papery layer of crushed tissue; the nucellus is possibly of the same nature.

The embryo is the "meat" of the nut. Each cotyledon consists of two lobes and each lobe is folded upon itself. The major septum lies between the two lobes so that half the cotyledon is in one carpel and half in the other carpel.

The greater part of the husk of the matured fruit is the involucre. A thin inner layer of the husk is the perianth. The husk splits off the shell in the perianth and outer carpel region. The shell is the greater part of the ovary wall.

The vascular system consists of an outer cycle of bundles ending in the involucre; an inner, perianth-carpel cycle; and an innermost group considered ventral bundles. The tissue between these first and second cycles is traversed by involucre bundle branches, variously oriented.

The bundles of the involucre cycle have normal orientation. The perianth-carpel region contains normal bundles that have arisen directly 
from the pedicel or as branches of the large bundles at the base of the fruit, and irregularly oriented bundles that are branches of the involucre system.

Four bundles of the perianth-carpel cycle that come to lie at the dorsal sutures are considered dorsal-ventrals. After the four ventrals branch toward the center, twisting to gain normal orientation in their ascending course, the two dorsals are formed by the union of two of these bundles at each shell suture.

The dorsal bundles end in the style. The ventral bundles unite two by two and produce two ovule branches, which in turn form a ring of tissue at the funiculus. The integument bundles arise from this ring.

There is no turning of bundles at the apex of the flower as found in Hicoria pecan.

\section{ACKNOWLEDGMENTS}

Dr. Warren P. Tufts suggested and initiated the problem by making the 1930 collections of material. The author wishes to thank Dr. Tufts, Dr. A. S. Foster, and Dr. L. D. Davis for suggestions and criticisms in the preparation of the manuscript, and Mr. L. R. McKinnon for making the photographs for the illustrations in the paper. 
1 Adriance, Guy.

\section{LITERATURE CITED}

1931. Factors influencing fruit setting in the pecan. Bot. Gaz. 91:144-166.

2 Benson, M., AND E. J. WELSFORD.

1909. The morphology of the ovule and female flower of Juglans regia and of a few allied genera. Ann. Bot. [London] 23:625-633.

3 Billings, F. H.

1903. Chalazogamy in Carya olivaeformis. Bot. Gaz. 35:134-135.

4 Braun, A.

1872. Über den inneren Bau der Frucht der Juglandeen. Bot. Ztg. 30:371-375.

5 CANDolle, C. DE

1862. Memoire sur la famille des Juglandees. Ann. Sci. Nat. Bot. Ser. IV, 18: $5-48$.

6 Holm, T.

1921. Morphological study of Carya alba and Juglans nigra. Bot. Gaz. 72:375389.

7 KARSTEN, G.

1902. Über die Entwickelung der weiblichen Blüthen bei einigen Juglandaceen. Flora [Jena] 90:316-333.

8 LANGDON, L. M.

1934. Embryogeny of Carya and Juglans, a comparative study. Bot. Gaz. 96: 93-117.

9 LUBBock, SiR JoHN.

1891. On the fruit and seed of the Juglandaceae. Jour. Linn. Soc. Bot. [London] 28:247-254.

10 NAWASCHIN, $\mathrm{S}$.

1895. Ein neues Beispiel der Chalazogamie. Bot. Centralb. 63:353-357.

11 Nicoloff, M. TH.

1904-5. Sur le type floral et le development du fruit des Juglandees. Jour. Bot. [Paris] 18:134-152, 280-285; 19:63-84.

12 Rowlee, W. W., ANd G. T. Hastings.

1898. The seed and seedlings of some Amentiferae. Bot. Gaz. 26:349-553.

14 SCHUHART, D. V.

1932. Morphology and anatomy of the fruit of Hicoria pecan. Bot. Gaz. 93:1-20.

14 SchuHART, D. V.

1927. The morphological differentiation of the pistillate flowers of the pecan. Jour. Agr. Research 34:687-697.

15 VAN TIEghem, $P$.

1861. Anatomie de la fleur femelle et du fruit du noyer. Bul. Soc. Bot. France $16: 412-419$.

16 Wooproof, J. G., AND N. C. Wooproor.

1926. Fruit bud differentiation and subsequent development of the flowers in Hicoria pecan. Jour. Agr. Research 33:677-685.

17 WOODROOF, J. G., AND N. C. WOODROOF.

1927. The development of the pecan nut (Hicoria pecan) from flower to maturity. Jour. Agr. Research 34:1049-1063.

18 WOODROOF, N. C.

1928. Development of the embryo sac and young embryo of Hicoria pecan

- (Brit.). Amer. Jour. Bot. 15:416-421.

19 WOODWORTH, ROBERT H.

1930. Meiosis of microsporogenesis in Juglandaceae. Amer. Jour. Bot. 17: 863-869. 
PLATES 1 To 19 


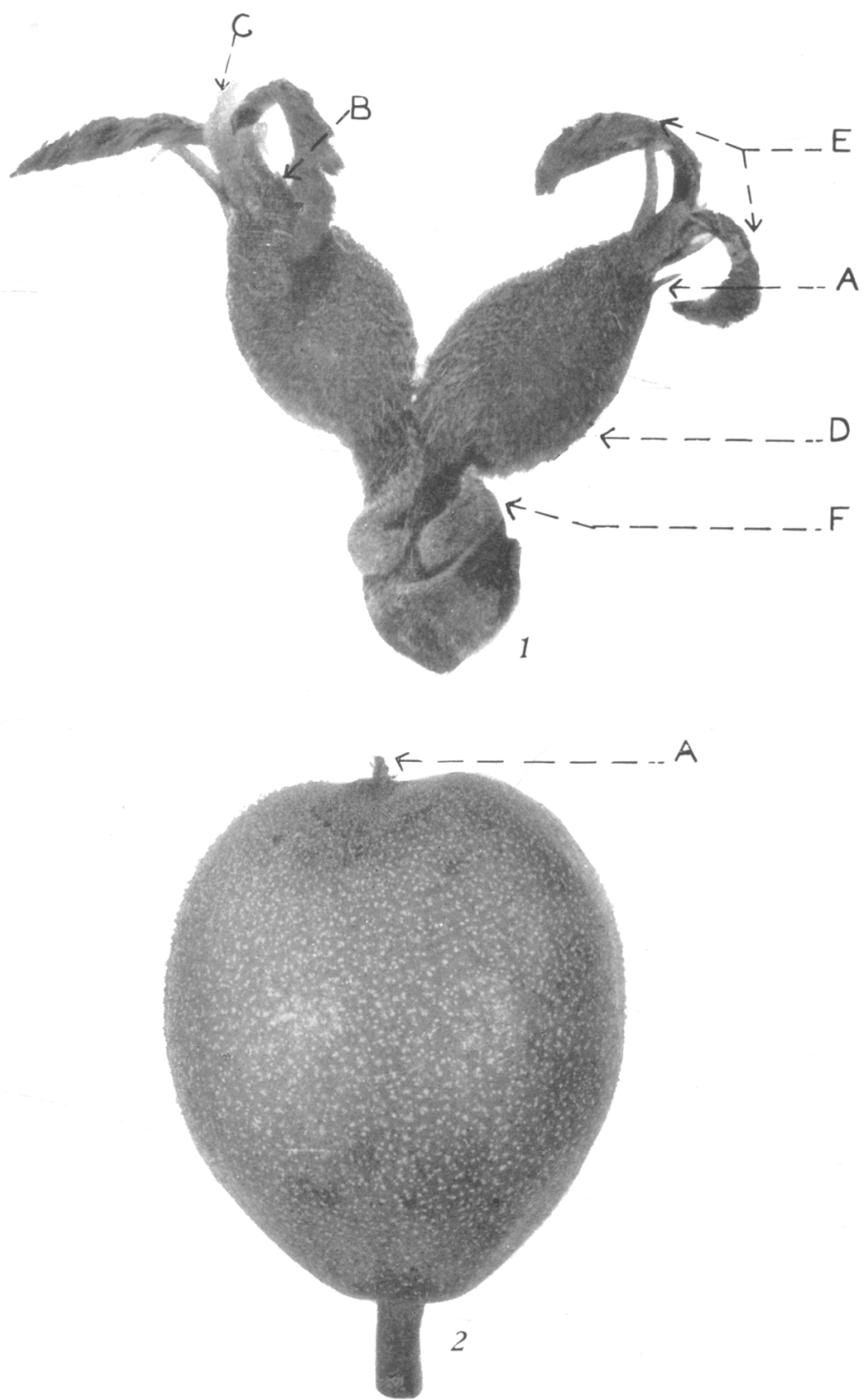

Fig. 1. Walnut inflorescence of two flowers: $A$, bract; $B$, fringe of bracteoles; $C$, perianth lobes; $D$, hairy involucre; $E$, stigmas; and $F$, bracts on peduncle. ( $\times 4$.)

Fig. 2. Mature walnut: $A$, remains of flower parts. (Natural size.) 

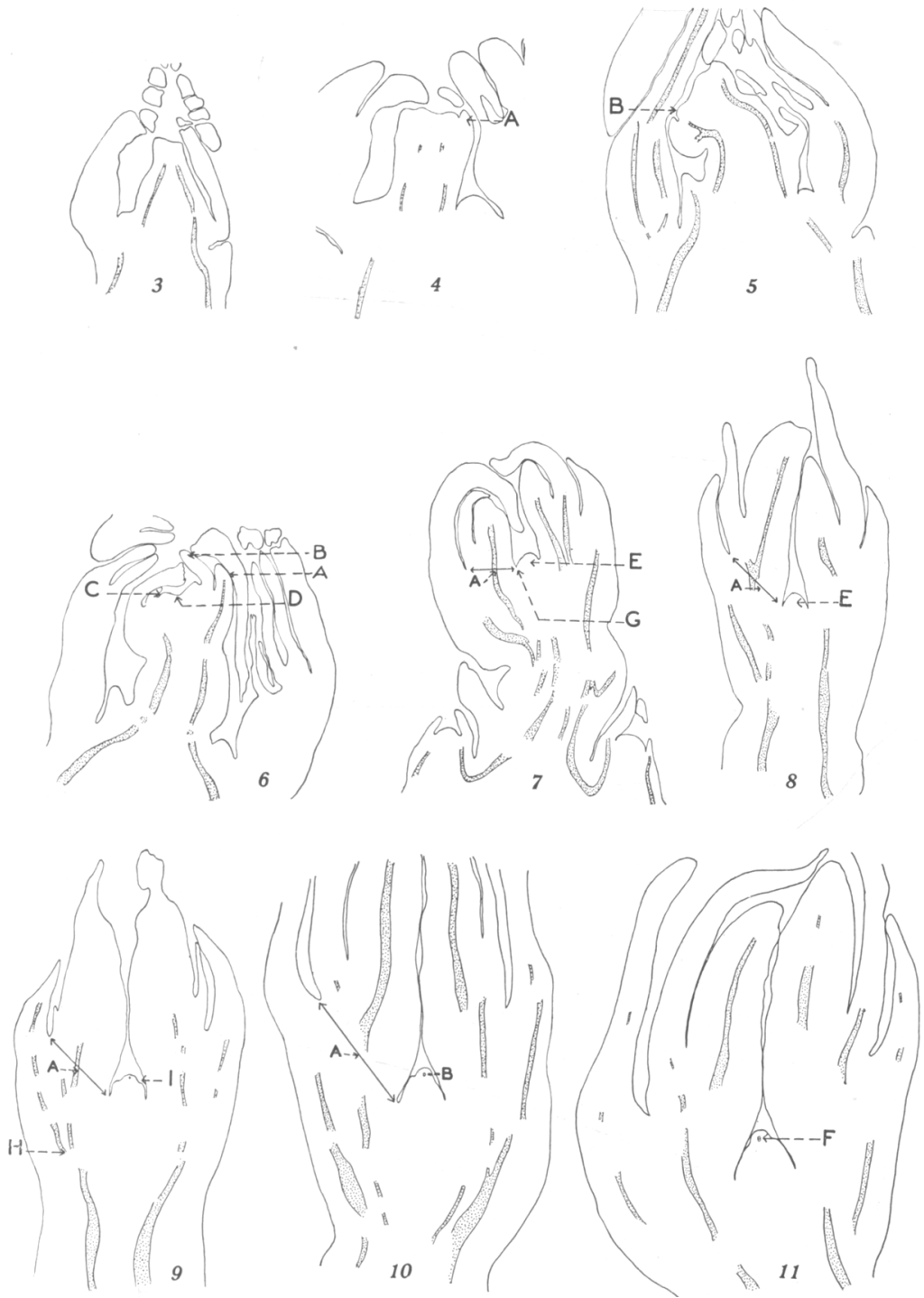

Figs. 3, 4. Buds collected February 25, 1930, showing flattened apex and beginning of involucre at $A$.

Fig. 5. Bud collected March 7, 1930, showing beginning of perianth at $B$.

Fig. 6. Bud collected March 15,1930 , showing involucre $A$, perianth $B$, beginning of pistil at $C$, and depression at $D$.

Fig. 7. Bud collected March 22, 1930, showing increase in size of bud and appearance of the central placenta at $E$. $A$, Region of intercalary growth. $G$, Central placenta filling entire base of ovarian cavity.

Figs. 8-11. Buds collected March 22, 1930, showing increase in size. Intercalary growth at $A$; central placenta $E$; ovule $I$; macrospore mother cell $B$; two daughter cells $F$; and provascular strands at $\boldsymbol{H}$.

(All figures $\times 22$.) 

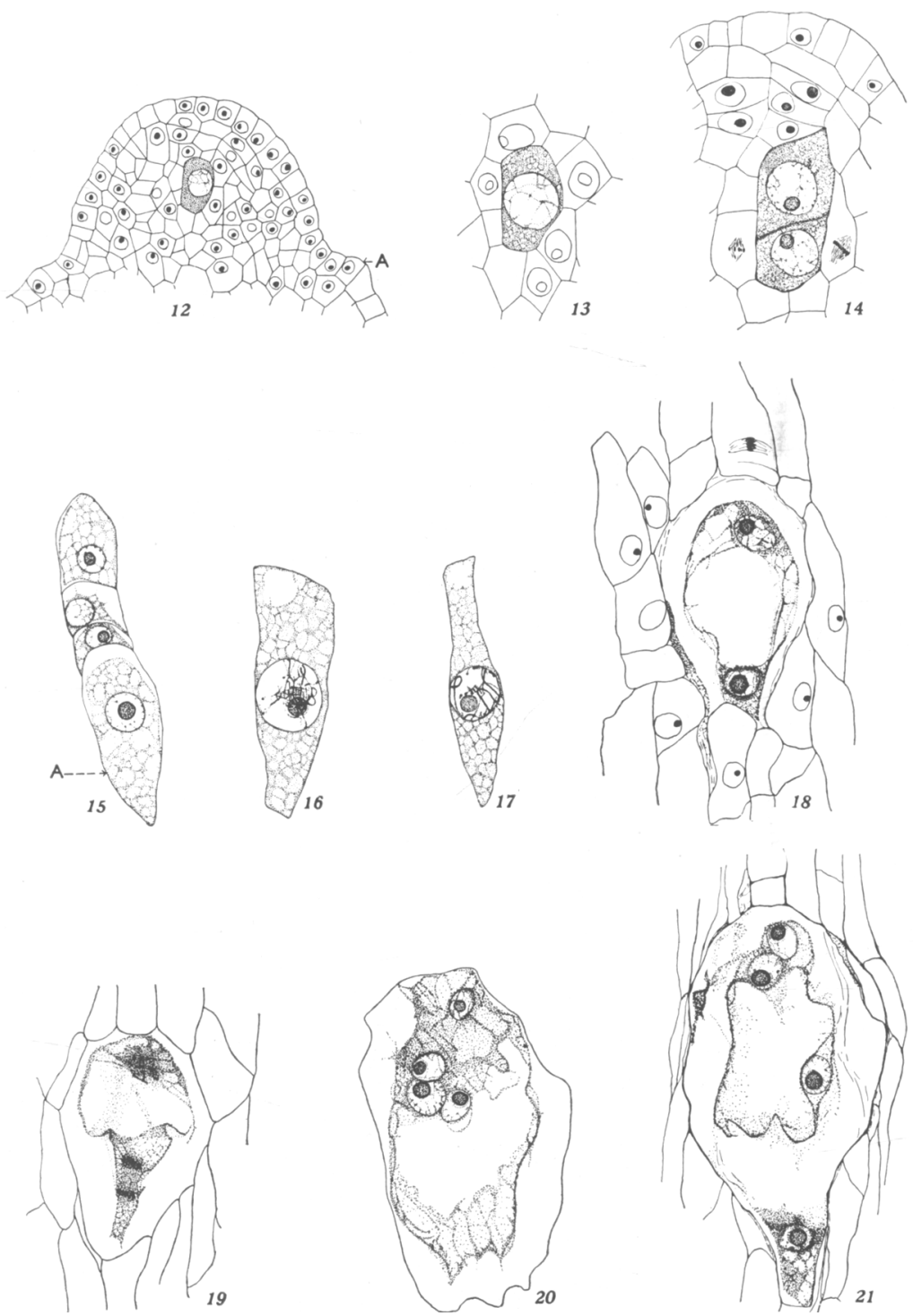

Fig. 12.-Ovule enlarged from plate 2, figure 10, shows macrospore mother cell and integument primordium at $A$.

Fig. 13. Macrospore mother cell enlarged from figure 12

Fig. 14. Daughter cells derived from macrospore mother cell.

Fig. 15. Linear tetrad with enlarged chalazal macrospore at $A$.

Figs. 16, 17. Macrospores showing increase in size of nuclei and cells.

Fig. 18. A two-nucleate stage.

Fig. 19. Second division in embryo sac.

Fig. 20. Four-nucleate stage with nuclei abnormally placed.

Fig. 21. Four-nucleate stage with nuclei in normal position.

(Figure 12, $\times 288$; figures $13-21, \times 575$.) 

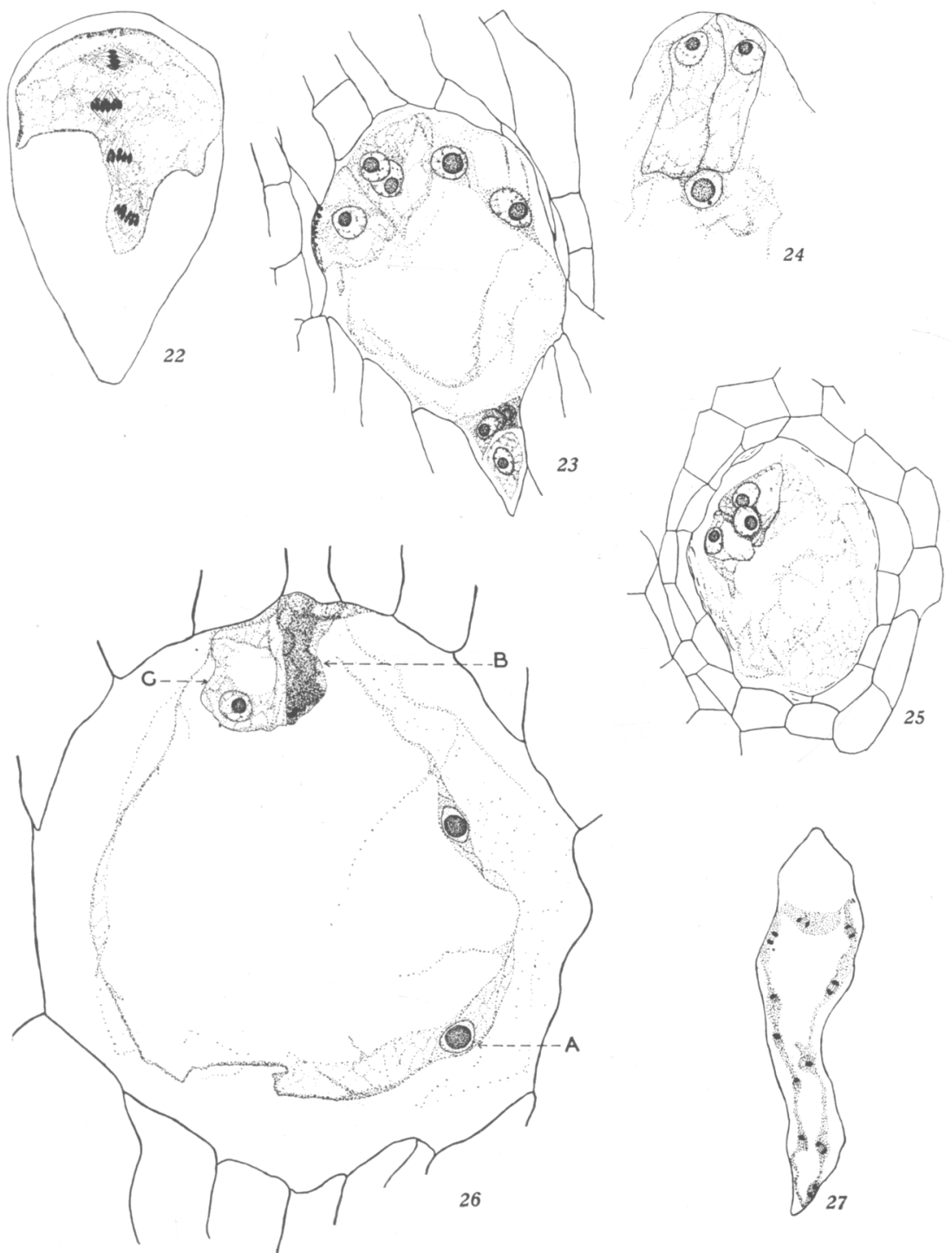

Fig. 22. Division leading to eight-nucleate stage.

Fig. 23. Mature macrogametophyte of eight nuclei and seven cells.

Fig. 24. Elongated synergid cells just before fertilization. One polar nucleus is present and shows the characteristic enlarged nucleolus. $(\times 538$.

Fig. 25. Transverse section of egg apparatus.

Fig. 26. Embryo sac showing one-celled embryo $C$ attached to micropylar end; disintegrating synergids $B$; and two endosperm nuclei $A$.

Fig. 27. Endosperm showing simultaneous division of nuclei.

(Figures $22-26, \times 625$; figure $27, \times 115$.) 
HILGARDIA, VOL. 9. NO. 7

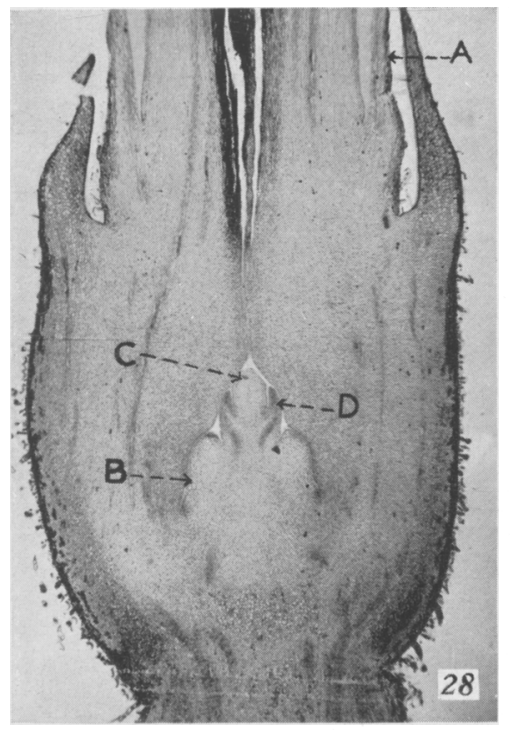

[NAST] PLATE 5
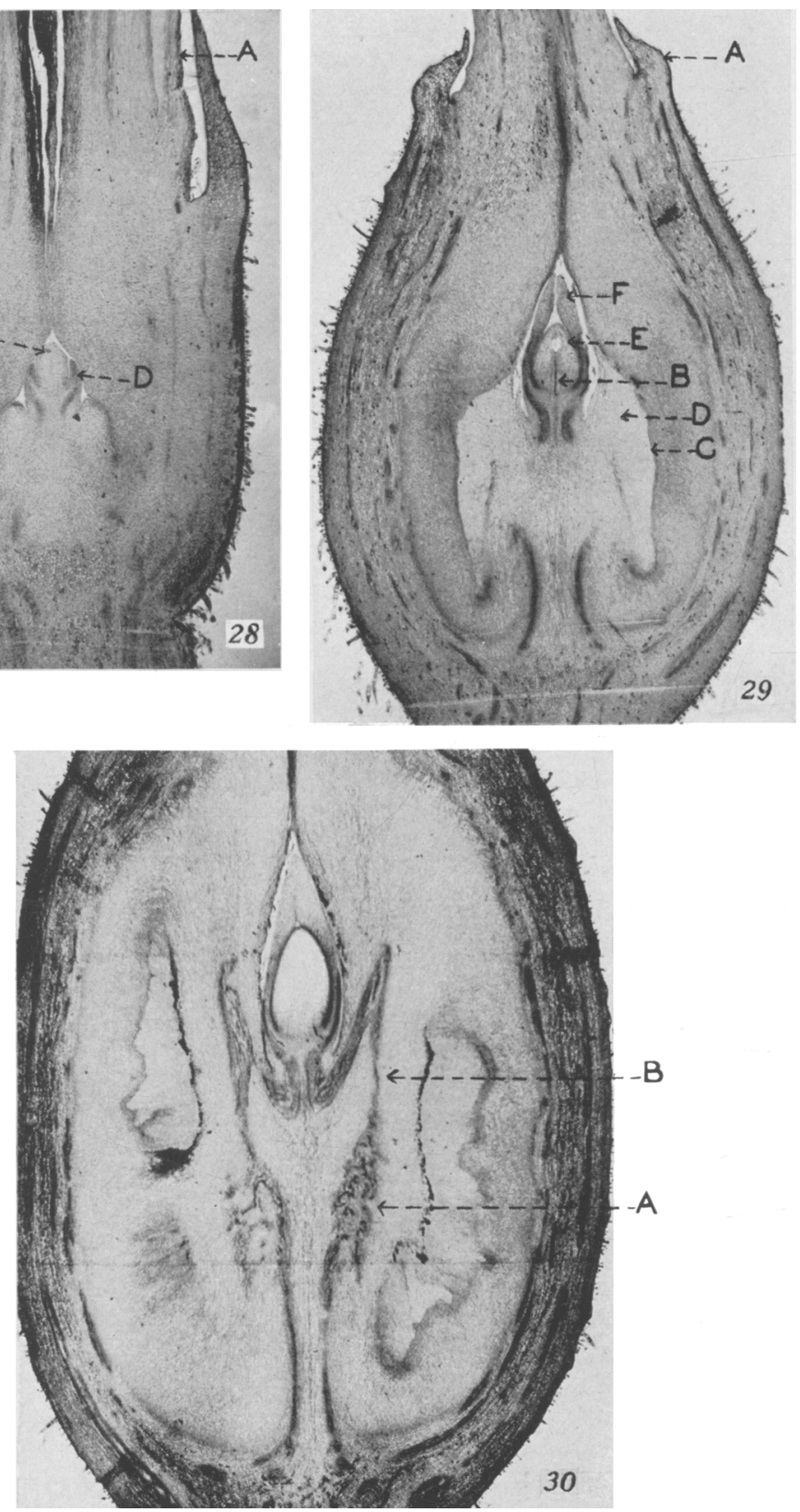

Fig. 28. Young flower in tetrad stage, showing perianth at $A$, evaginations at $B$, nucellus at $C$, and integument at $D$. $(\times 18$.

Fig. 29. Longitudinal section of flower after fertilization: $A$, involucre; $B$, pollen tube; $C$, line of separation between evaginations and carpel wall; $D$, evaginations; $E$, conical nucellus; and $F^{\prime}$, integuments. $(\times 10$.

Fig. 30 . Longitudinal section of flower showing sessile ovule; ventral bundles at $B$, and branches at $A$ which feed the winged evaginations. $(\times 8$. 

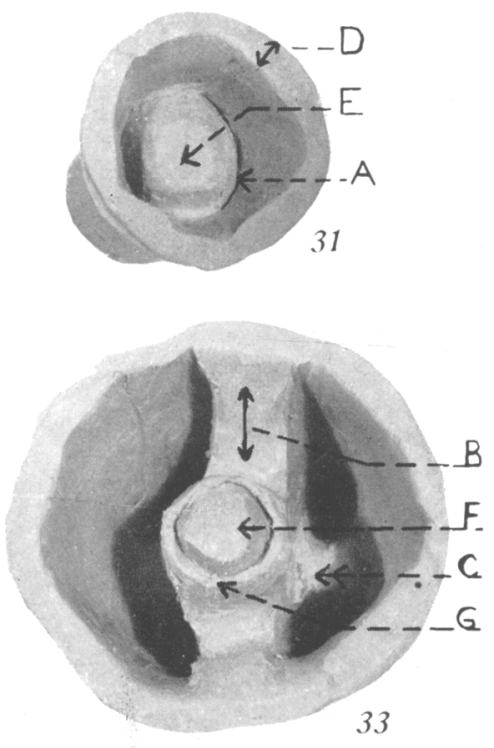
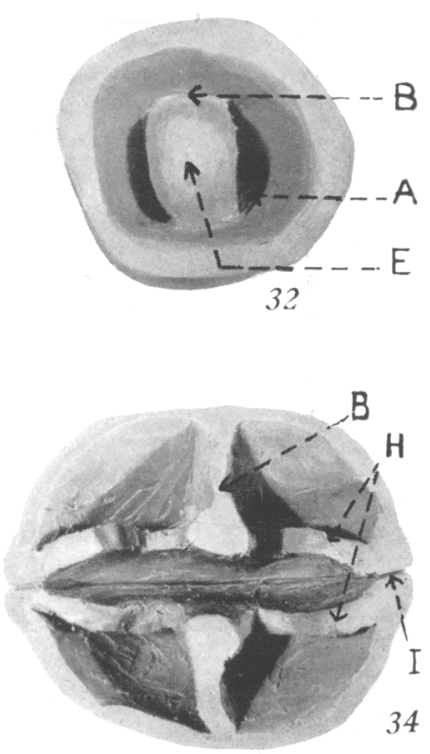
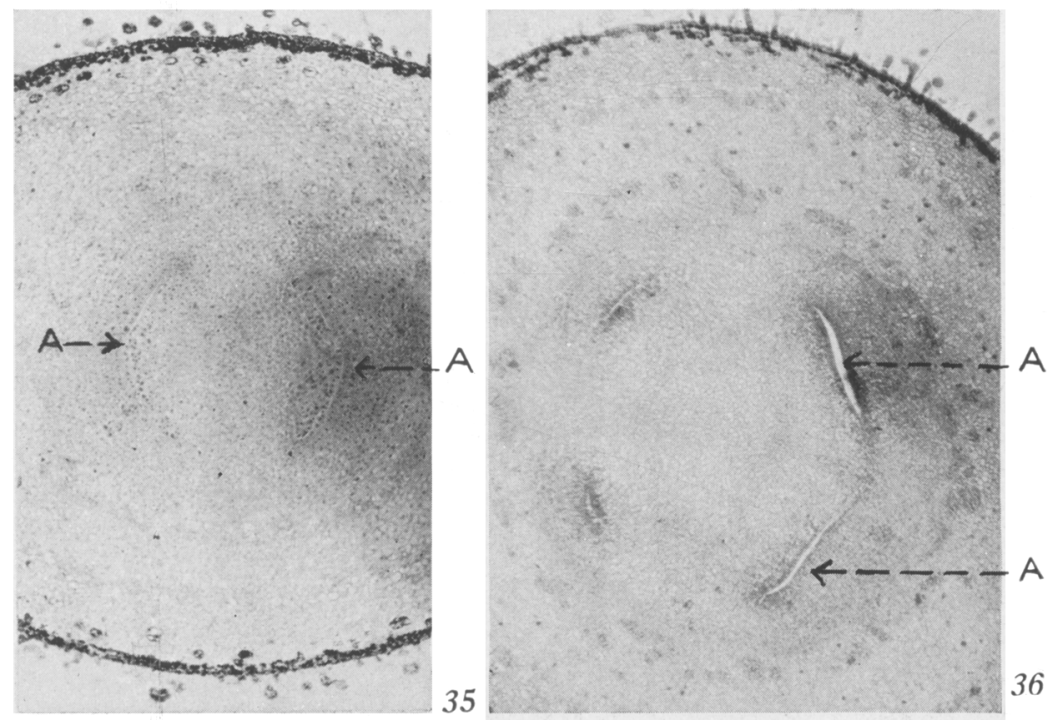

Figs. 31-33. Models to show development of the septa: A, crack formed by separating cells at the bottom of the ovarian cavity; $B$, major septum; $C$, second septum; $D$, walls of involucre, perianth, and carpel; $E$, placenta; $F$, ovule; and $G$, integument.

Fig. 34. Model showing septa at apical end of shell: $B$, major septum; $H$, second septum ; $I$, dorsal suture.

Fig. 35. Transverse section of young flower, showing the separation of cells at $A$, which is the beginning of the formation of the major septum. ( $X 32$.)

Fig. 36. Transverse section of a young flower, showing the separation of cells at four places (A) and the beginning of the second septum. ( $\times 32$.) 

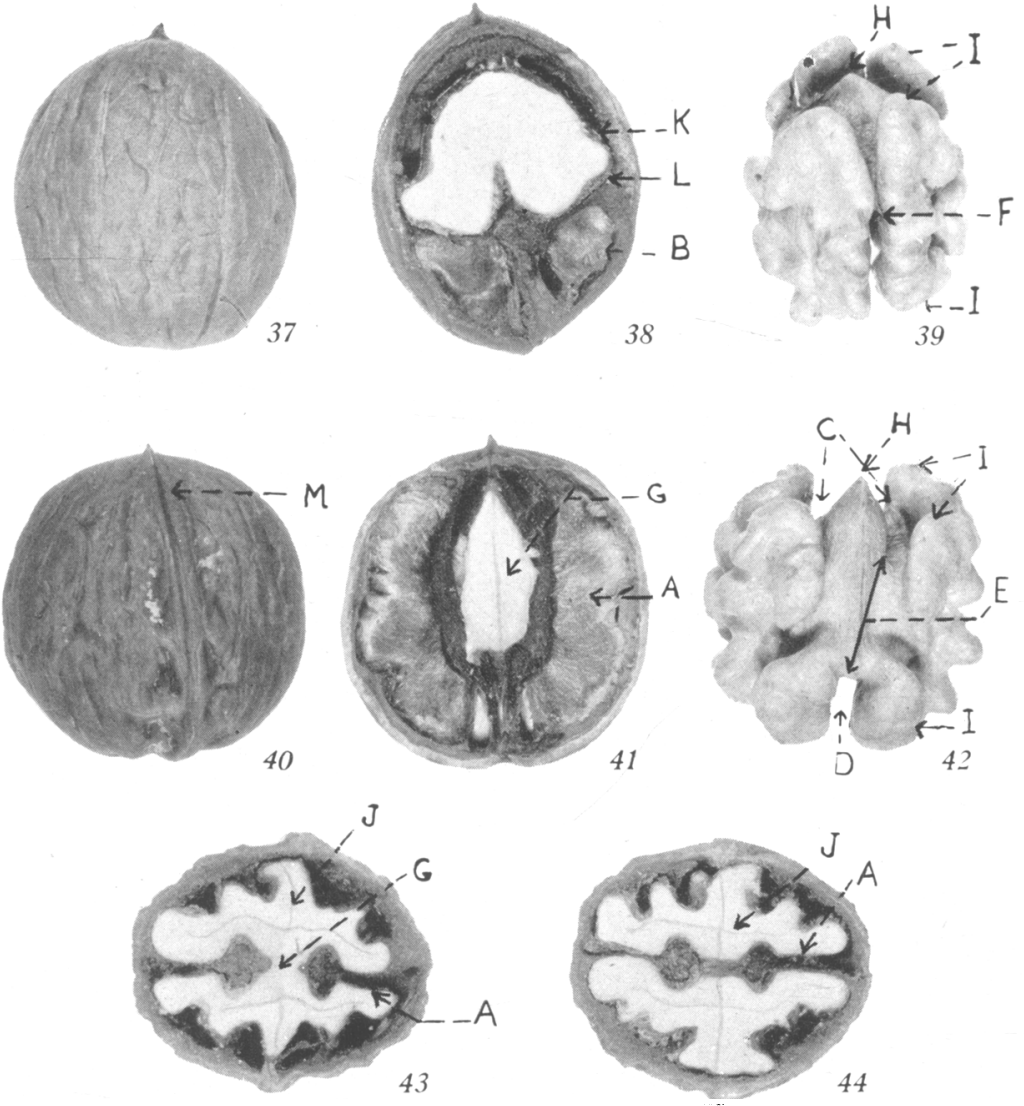

Fig. 37. Shell seen in a plane at a right angle to the major septum.

Fig. 38. "Nut" cut through dorsal sutures: $B$, lower second septum; $K$, lower limit of upper second septum; $L$, upper limit of lower septum.

Fig. 39. Seed placed as it would lie in the shell shown in figure $37: H$, hypocotyl end; $I$, points of the cotyledons; $F$, groove left by the major septum.

Fig. 40 . Shell seen in a plane at a right angle to the second septum. $M$, Dorsal suture, overlying the second septum.

Fig. 41. "Nut" cut through major septum or at right angles to dorsal sutures. $G$, seed and central region not bisected by major septum $A$.

Fig. 42. Seed placed as it would lie in the shell shown in figure $40: H$, hypocotyl; $I$, points of cotyledons; $C$, grooves left by upper second septum; $D$, groove left by the lower second septum; and $E$, region left unbisected by the second septa.

Figs. 43-44. "Nut" cut through region where seed is attached to placenta: $G$, upper part of fruit not bisected by the major septum; $A$, major septum; and $J$, place where the folds of the cotyledons meet and region where remains of the endosperm are found.

(All figures $\times 0.8$.) 

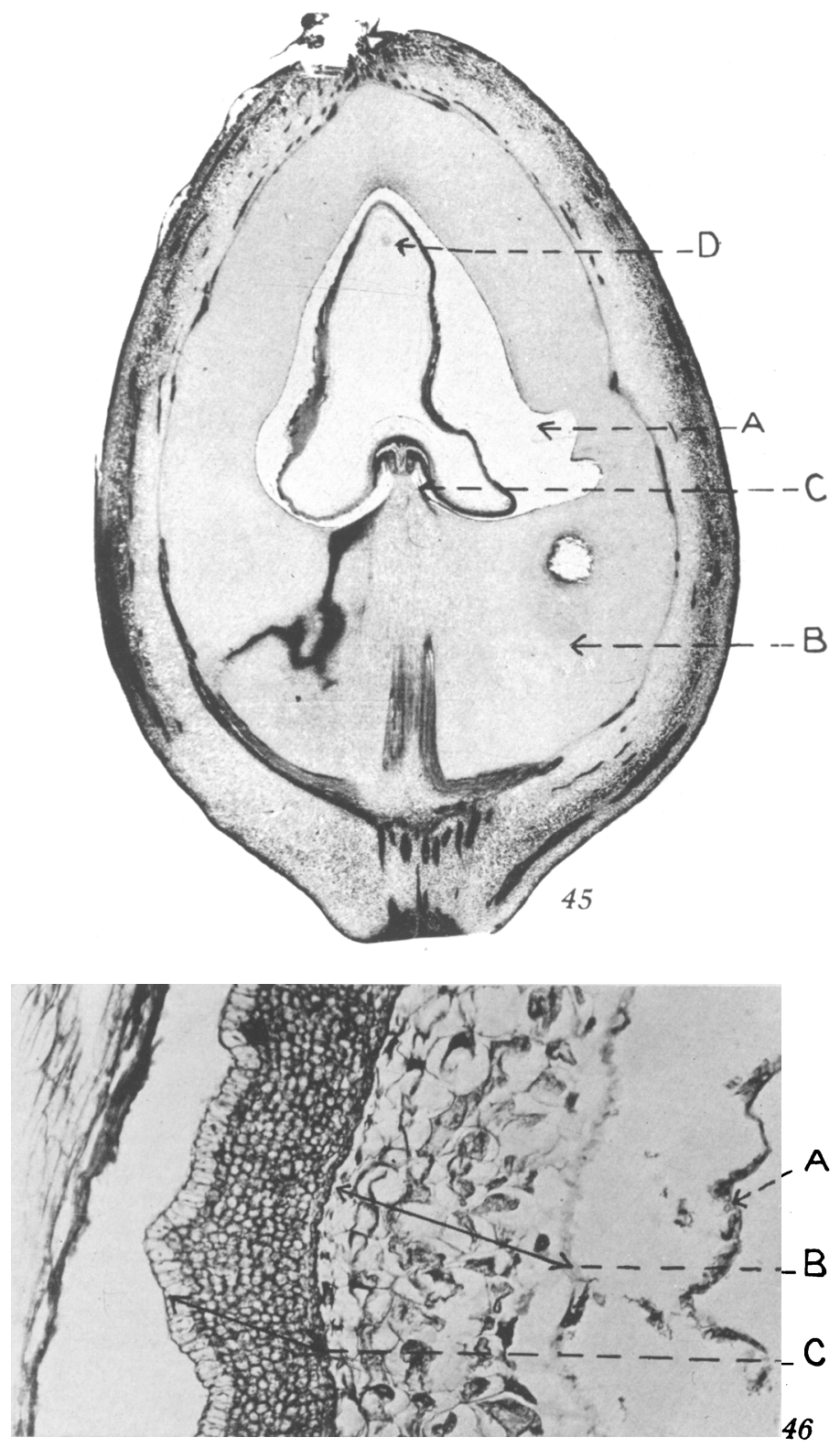

Fig. 45. Longitudinal section of a young fruit through the second septum $B: A$, space left after evaginations disintegrate; $C$, funiculus; and $D$, embryo. ( $\times 3$.

Fig. 46. Portion enlarged from figure 45: $A$, endosperm; $B$, nucellus; and $C$, integument. 

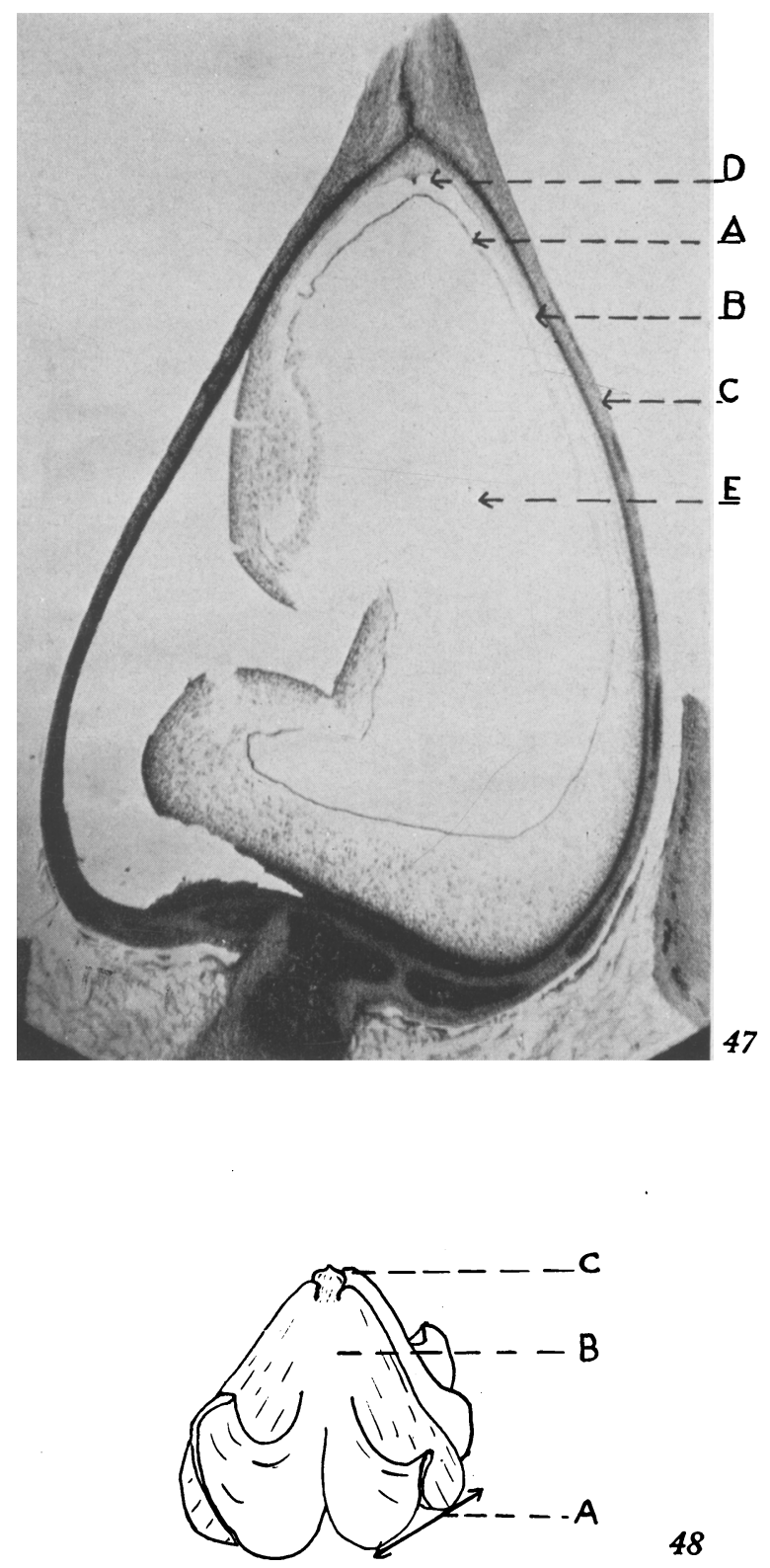

Fig. 47. Longitudinal section of a maturing ovule: $A$, endosperm; $B$, nucellus ; $C$, integument ; $D$, embryo; $E$, vacuole of endosperm. $(\times 16$. $)$

Fig. 48. Drawing of an embryo $13 \mathrm{~mm}$ long: $A$, one lobe of cotyledon $B ; C$, hypocotyl. 

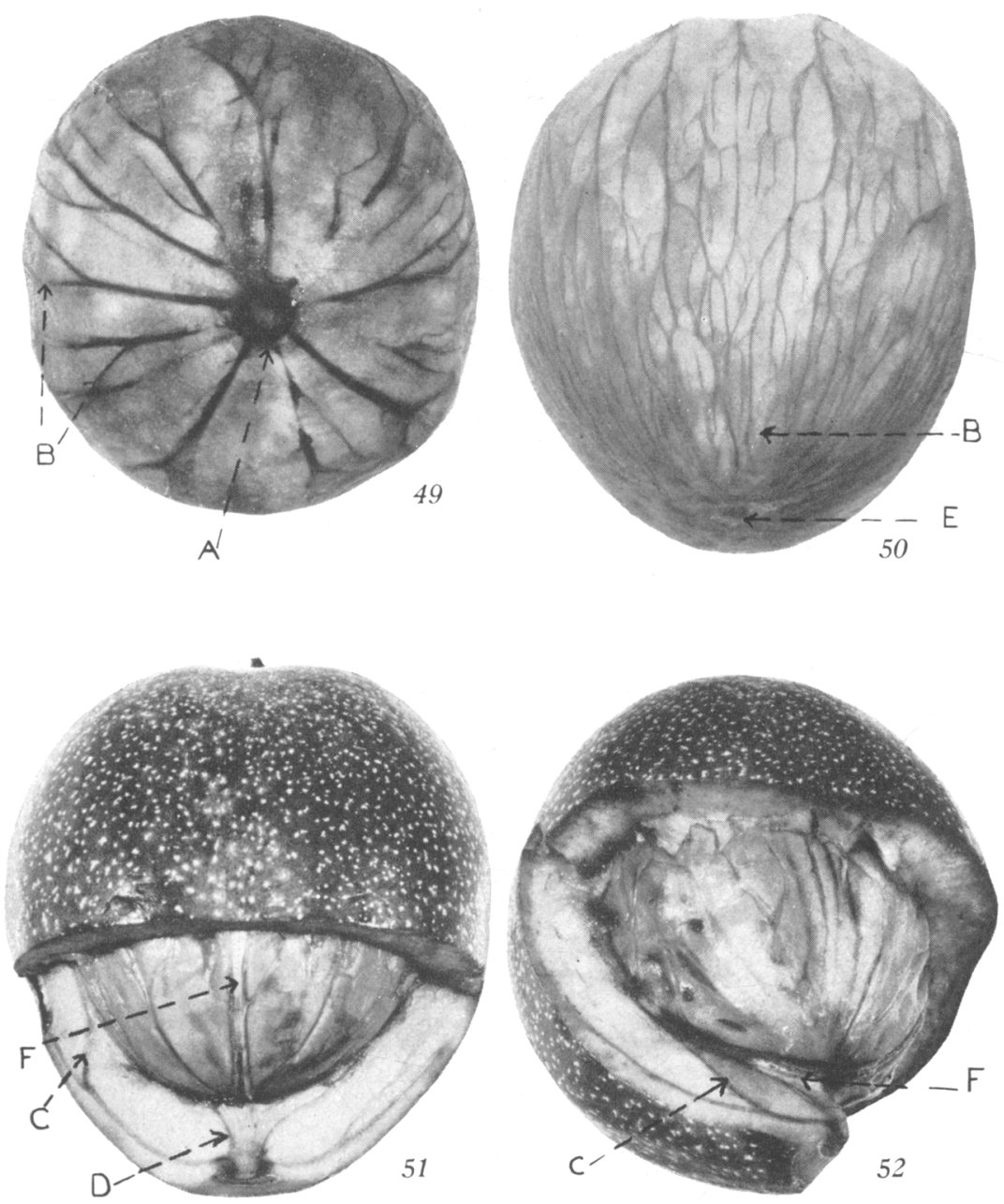

Fig. 49. A mature fruit with the outer part of the involucre peeled off to show vascular bundles. $A$, pedicel end of fruit; $B$, involucre bundles branching in the tangential plane.

Fig. 50. Same as figure 49 , but showing the stylar end of the fruit. $B$, mass of branches from main involucre bundles derived from pedicel; $E$, style scar.

Fig. 51. Fruit with involucre and perianth cut at right angles to the dorsal suture $F$ : $C$, radial branch of an involucre; $D$, perianth-carpel bundles.

Fig. 52. Fruit cut at dorsal suture $F: C$, radial branch of an involucre bundle.

(All figures natural size. The vascular bundles are stained with eosin.) 


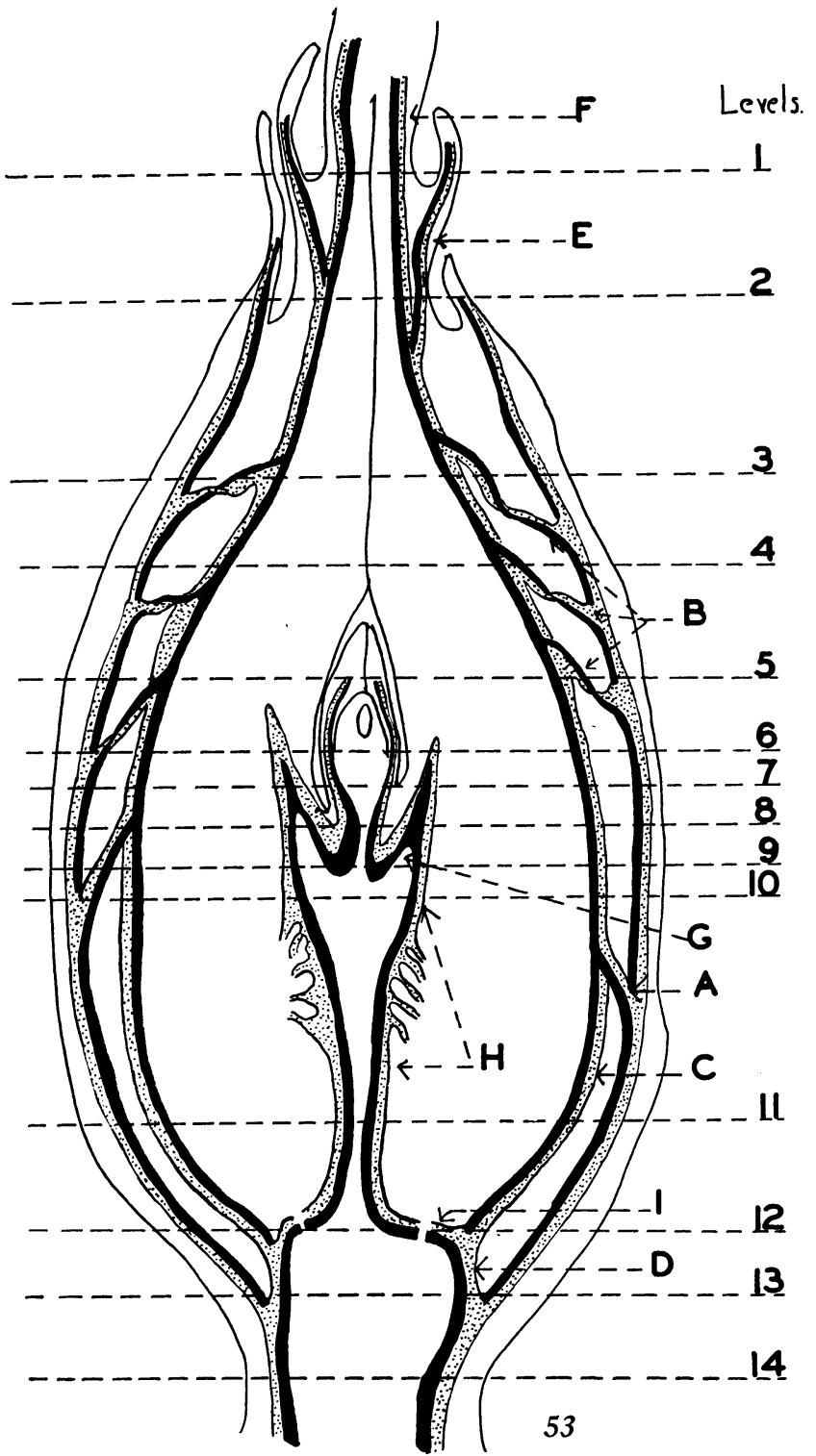

Fig. 53. Diagram of a longitudinal section of a flower through the major septum. Xylem is indicated in black; phloem is stippled. $A$, Normally oriented branch from involucre to perianthcarpel cycle $; B$, twisted branch or one of reversed orientation; $C$, perianth-carpel cycle; $D$, perianth-carpel bundle from pedicel; $E$, perianth bundle; $F$, bundle of style; $G$, ovule trace; $H$, ventral bundles; $I$, accessory branches joining the ventral bundles.

, The levels correspond to regions where sections of the flower in figures 55-68 are taken. The section shown in figure 55 is taken at level 1 ; figure 56 at level 2 , etc. 


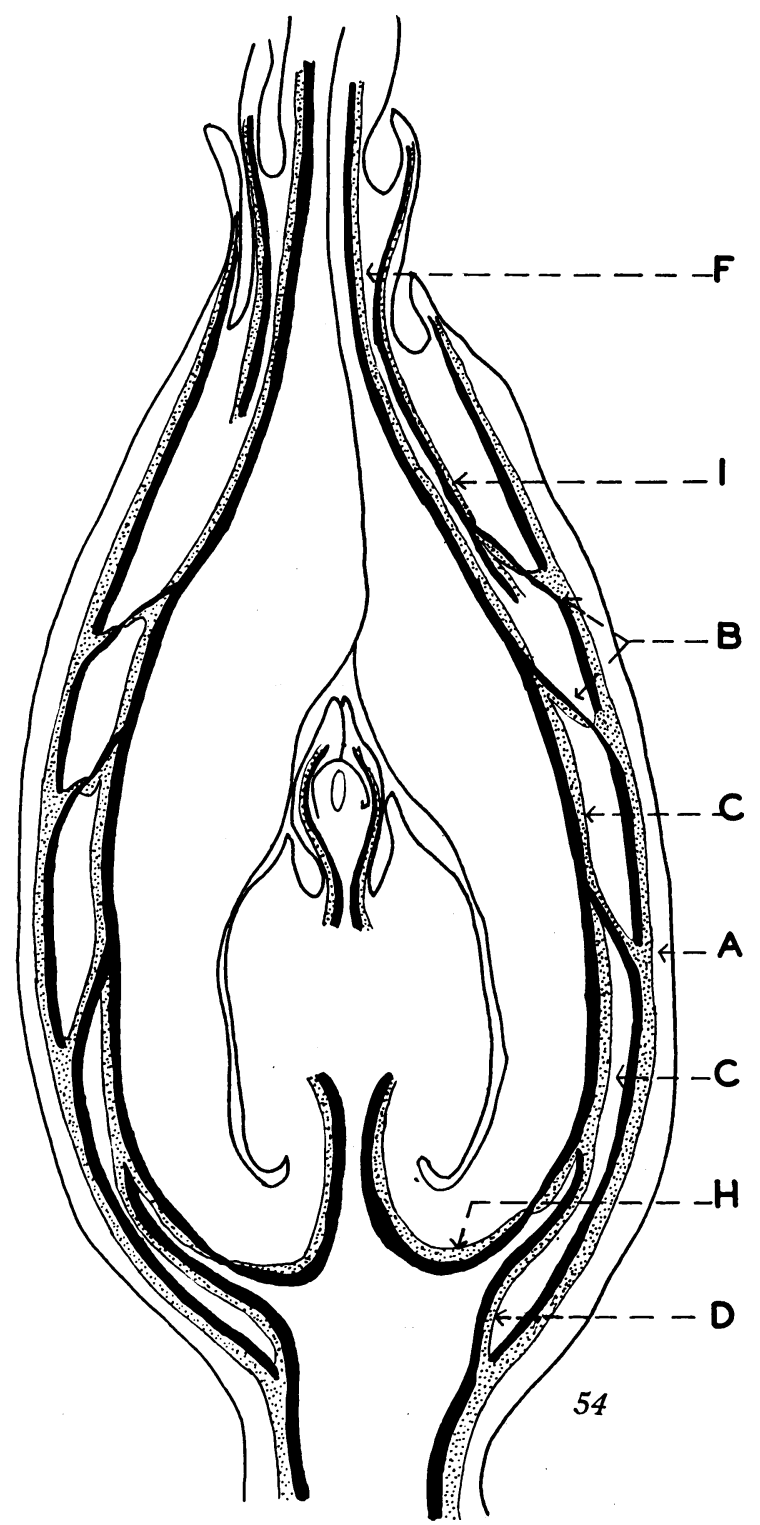

Fig. 54.-Diagram of a flower cut through the evaginations and dorsal suture, at right angles to the major septum. $A, B$, and $H$ are the same as in plate 11 (fig. 53); $C$, dorsal bundle; $D$, perianth-carpel bundle from pedicel-in this case the dorsal-ventral bundle; $F$, dorsal bundle in the style; $I$, perianth bundle which lies opposite the dorsal bundle and enters the lower set of perianth lobes. 

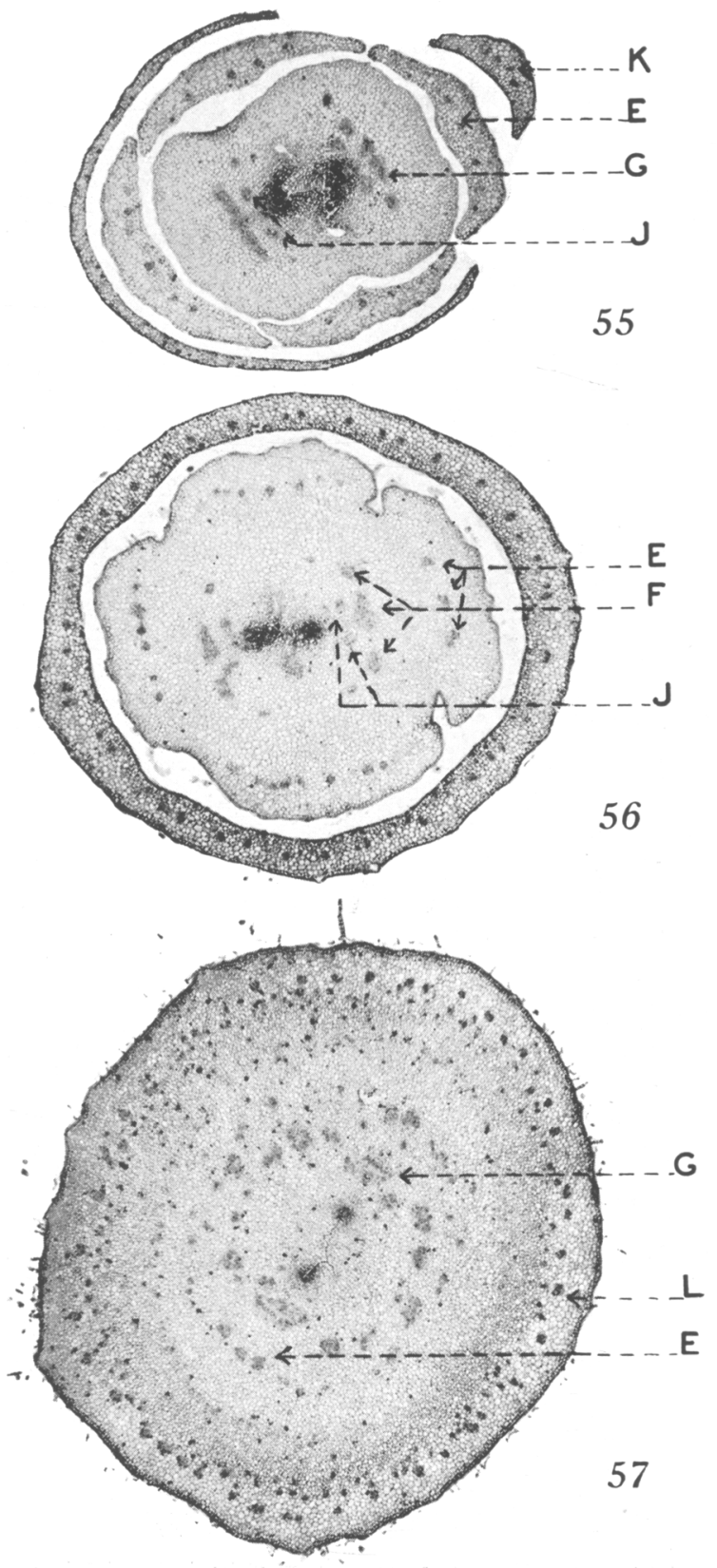

Figs. 55-57. Cross sections of a flower taken at levels 1 to 3 in plate 11 (fig. 53): $E$, perianth bundle; $F$, carpellary bundles plus dorsals; $G$, dorsal bundles; $J$, dorsal branches in style; $K$, bract trace; $L$, involucre bundles. $(\times 26$. 

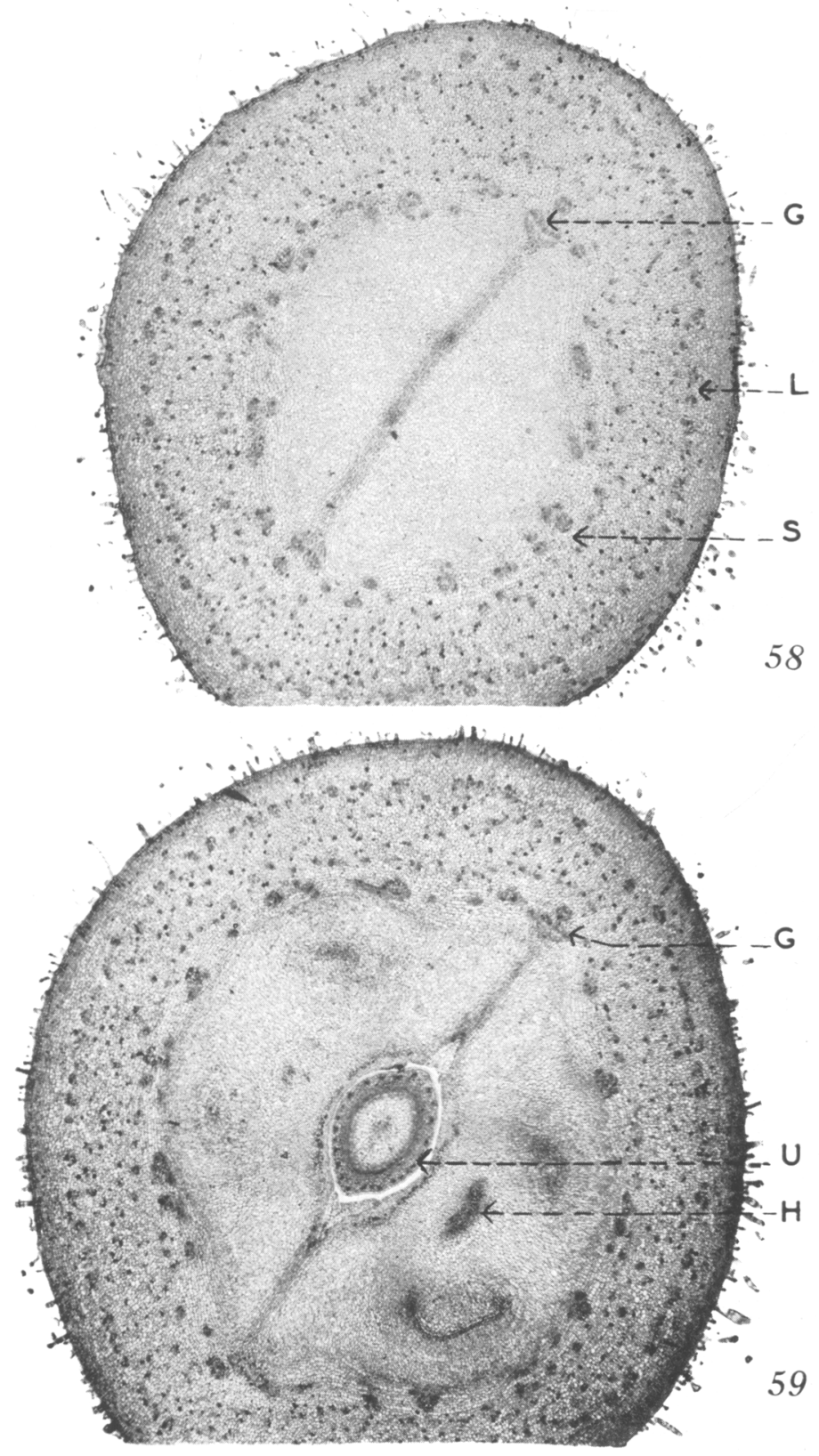

Figs. 58, 59. Cross sections of the same flower taken at levels 4 and 5 in plate 11 (fig. 53): $G$, dorsal bundles; $H$, ventral bundles; $L$, involucre bundles; $S$, perianth-carpel cycle; $U$, integument bundles. ( $\times 26$.) 

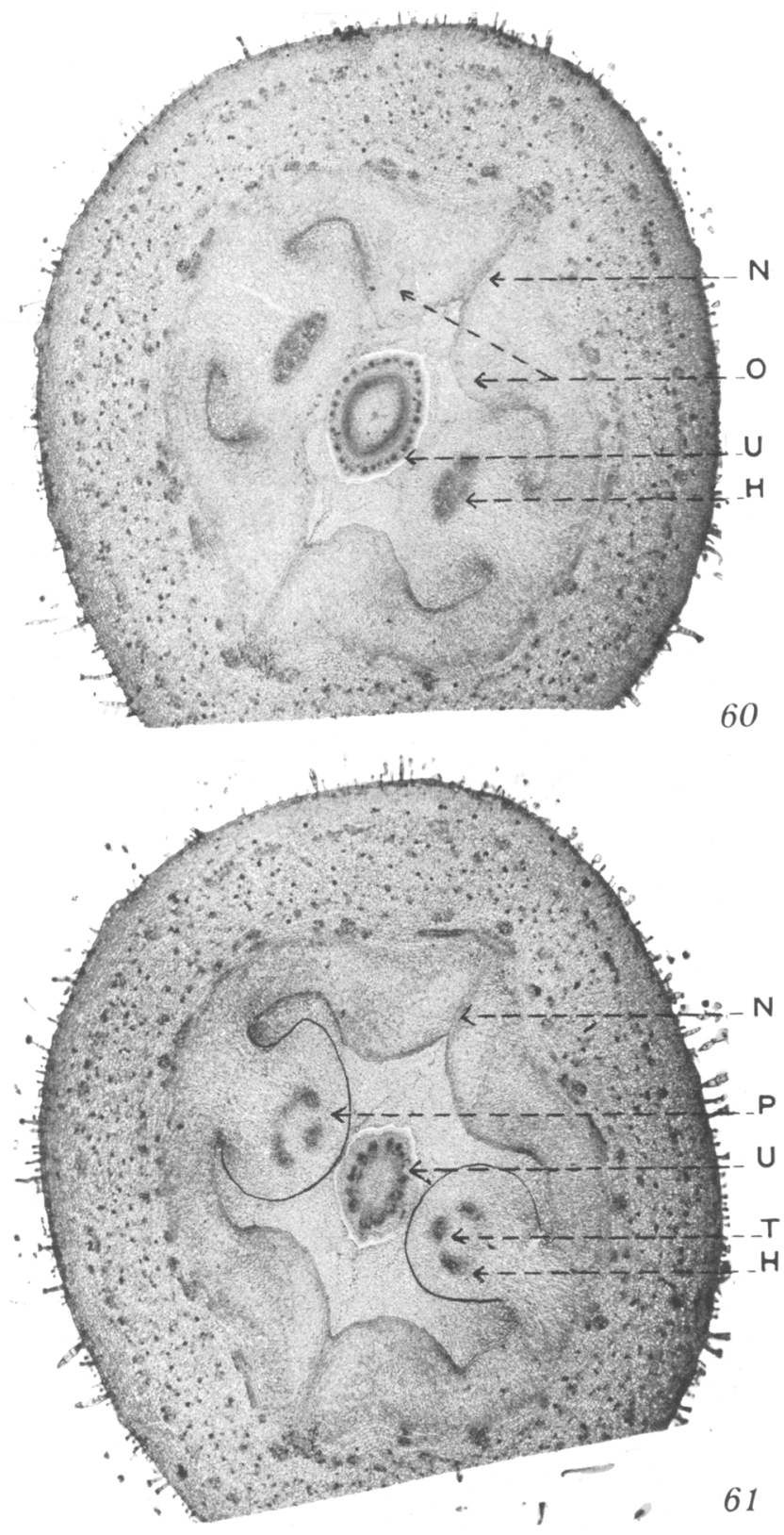

Figs. 60, 61. Cross sections of the same flower taken at levels 6 and 7 in plate 11 (fig. 53): $H$, ventral bundles; $N$, dorsal suture; $O$, second septum ; $P$, major septum $T$, ovule traces; $U$, integument bundles. $(\times 26$. 

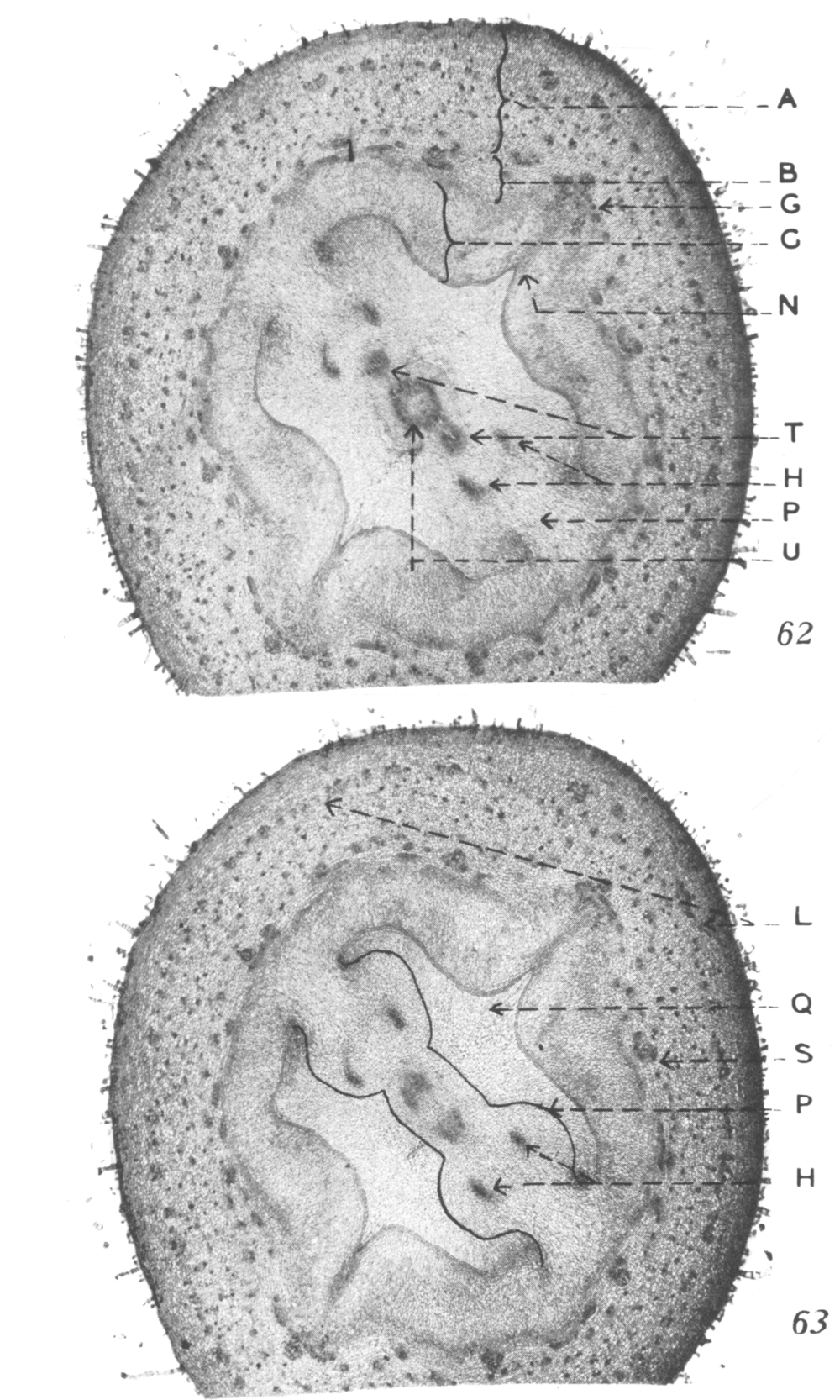

Figs. 62, 63. Cross sections of the same flower taken at levels 8 and 9 in plate 11 (fig. 53): $A$, involucre; $B$, perianth and small outer portion of carpel; $C$, shell or remainder of carpel wall; $G$, dorsal bundles; $H$, ventral bundles ; $L$, involucre bundles; $N$, dorsal suture; $P$, major septum; $Q$, evaginations; $S$, perianth-carpel cycle; $T$, ovule traces; $U$, integument bundles. $(\times 26$.) 


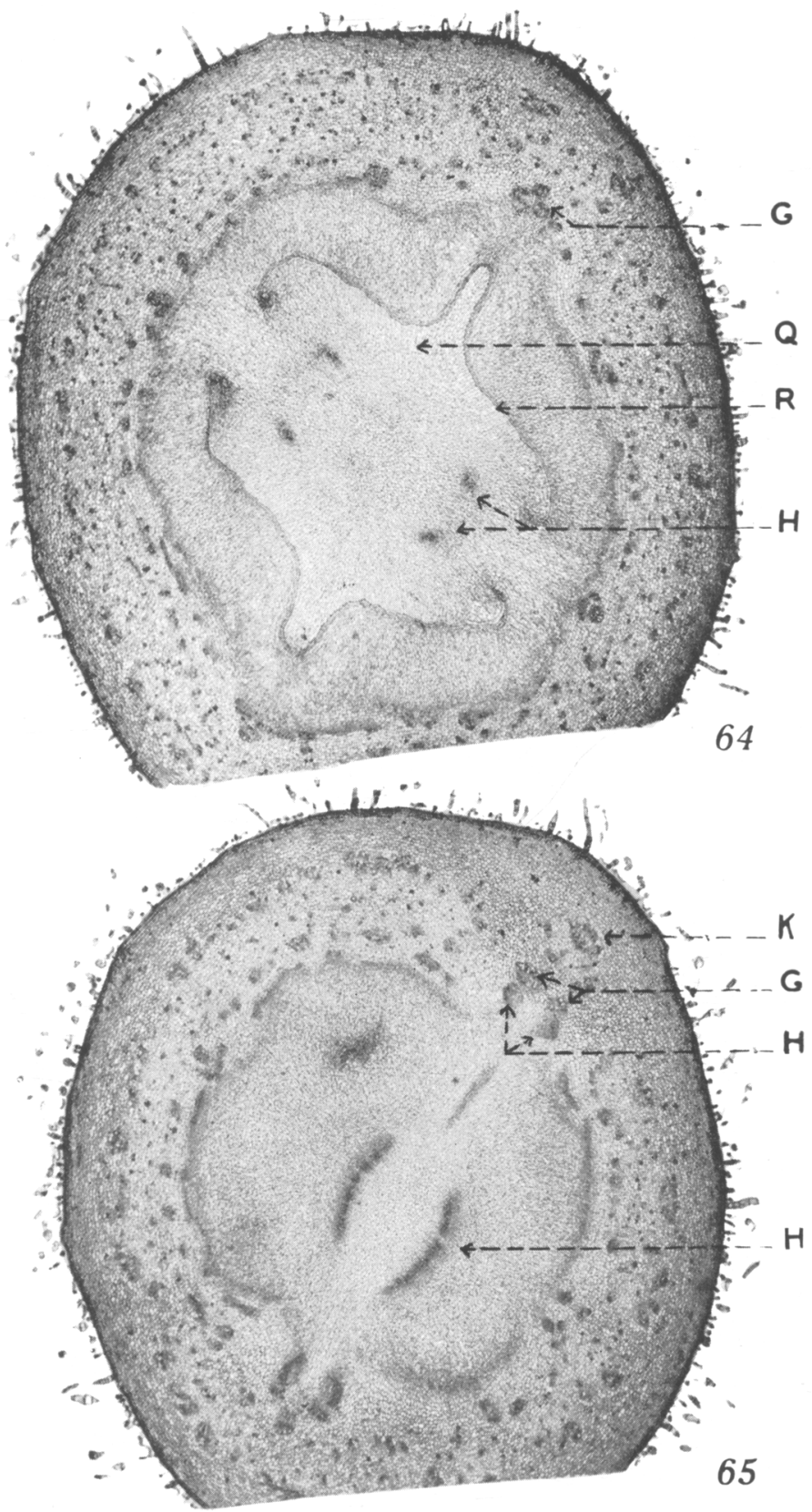

Figs. 64, 65. Cross sections of the same flower taken at levels 10 and 11 in plate 11 (fig. 53): $G$, dorsal bundles; $\boldsymbol{H}$, ventral bundles; $K$, bract trace; $Q$, evaginations; $R$, line of separation between the carpel wall and evagination. ( $\times 26$.) 

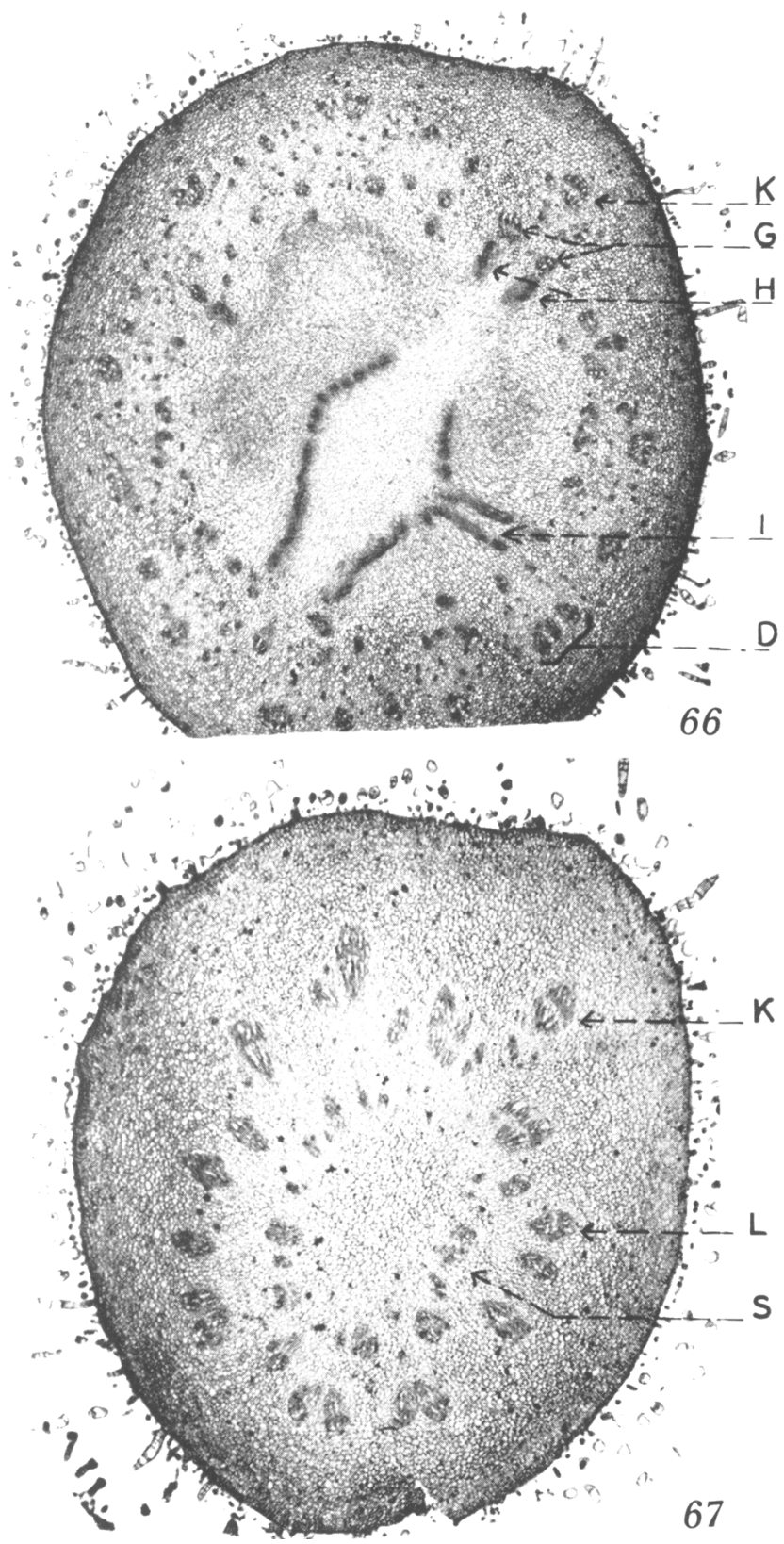

Figs. 66, 67. Cross sections of the same flower taken at levels 12 and 13 in plate 11 (fig. 53): $D$, group of bundles arising from one involucre bundle; $G$, dorsal bundles; $H$, ventral bundles : $I$, accesspry bundles; $K$, bract trace; $L$, involucre bundles; $S$, perianth-carpel cycle. $(\times 26$.) 

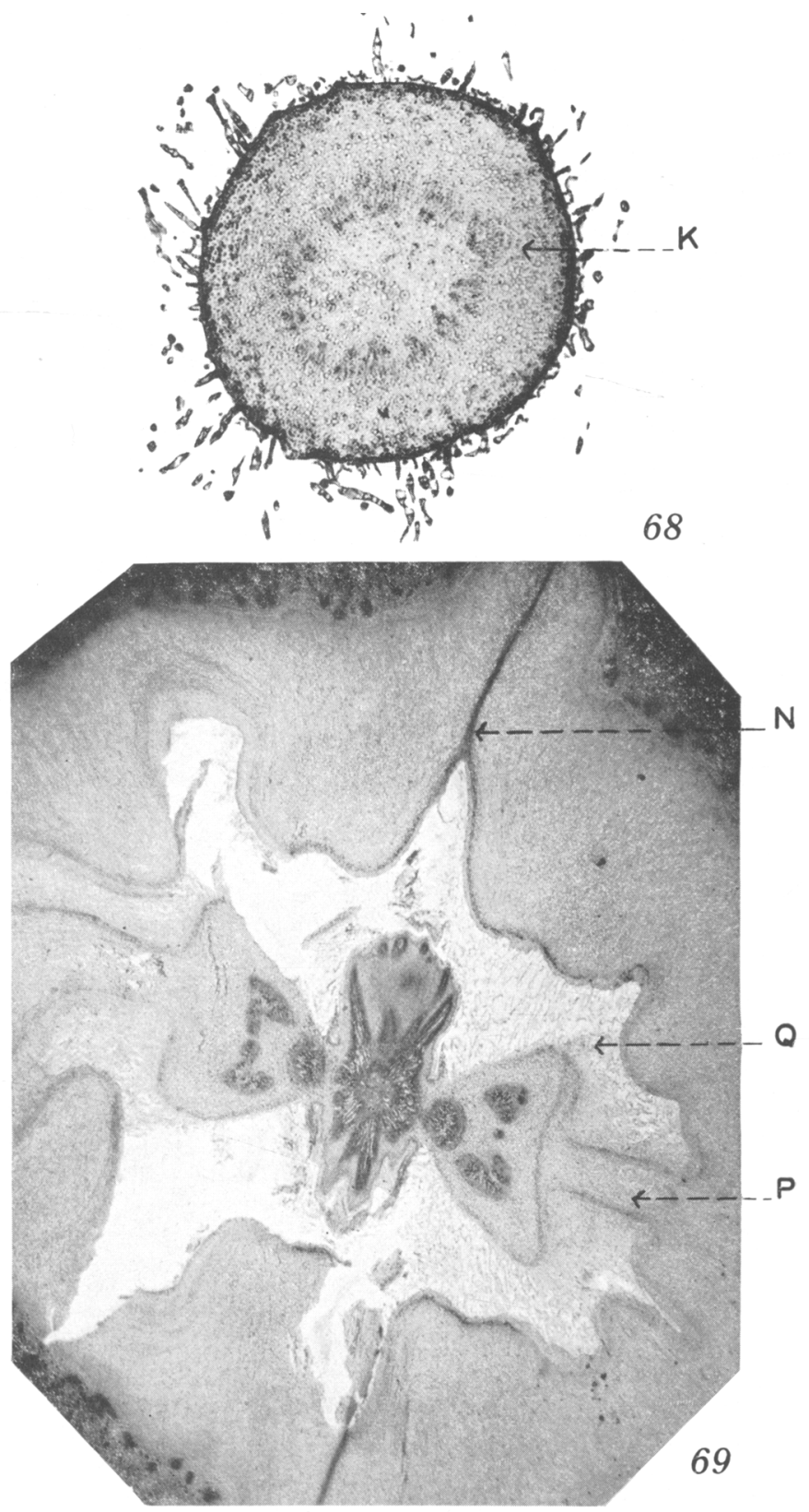

Fig. 68. Cross section of same flower taken at level 14 in plate 11 (fig. 53): $K$, bract trace. $(\times 26$.

Fig. 69. Shows major septum at $P$ and disintegrating evaginations at $Q$. $N$, Dorsal suture. $(\times 11$. 